$1-1-1962$

\title{
Marketing of lumber produced by sawmills in the Northeast.
}

\author{
Wallance W. Christensen
}

Follow this and additional works at: https://researchrepository.wvu.edu/ wv_agricultural_and_forestry_experiment_station_bulletins

\section{Digital Commons Citation}

Christensen, Wallance W., "Marketing of lumber produced by sawmills in the Northeast." (1962). West Virginia Agricultural and Forestry Experiment Station Bulletins. 478.

https://researchrepository.wvu.edu/wv_agricultural_and_forestry_experiment_station_bulletins/450 @ WVU. It has been accepted for inclusion in West Virginia Agricultural and Forestry Experiment Station Bulletins by an authorized administrator of The Research Repository @ WVU. For more information, please contact ian.harmon@mail.wvu.edu. 



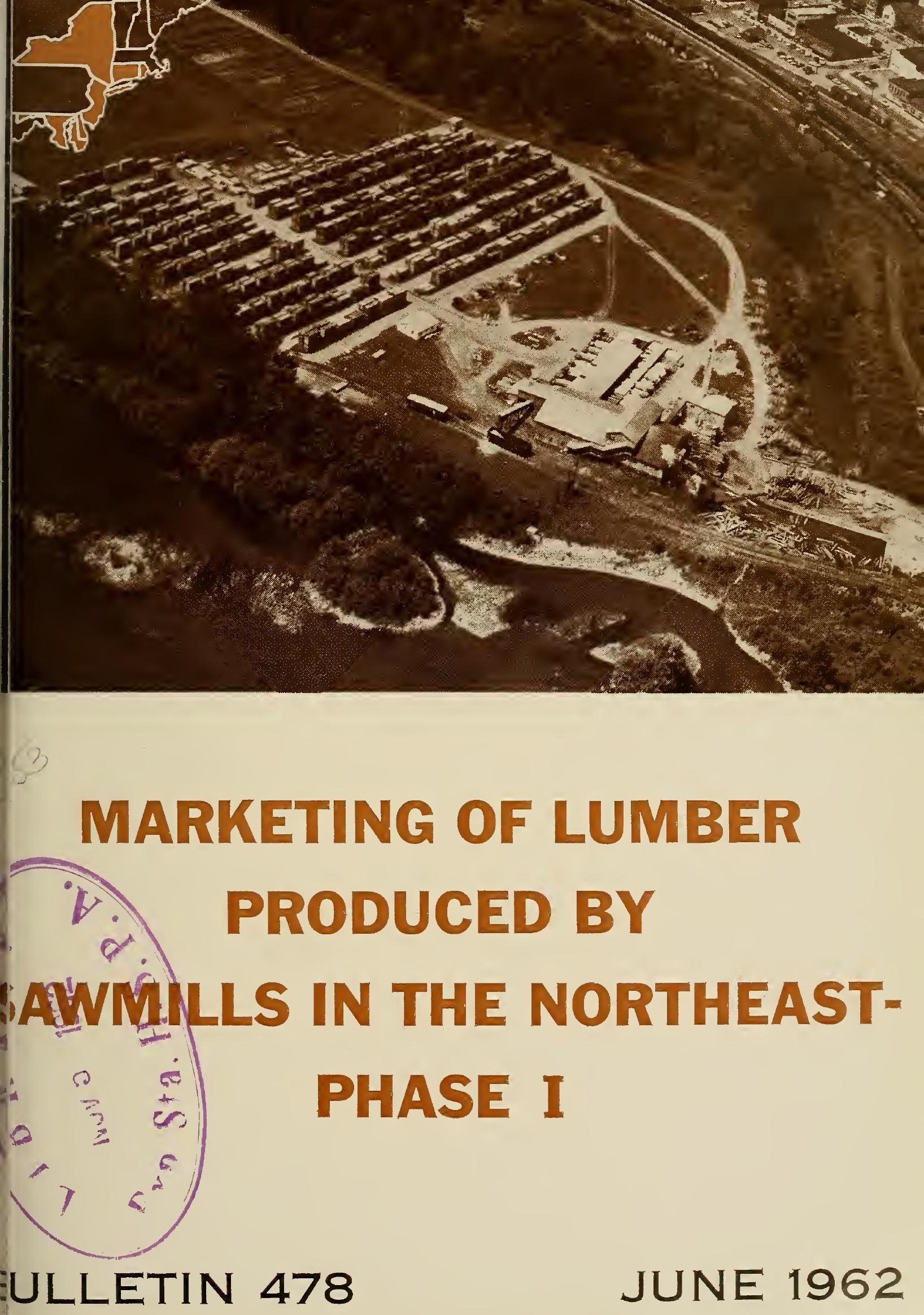

ST VIRGINIA UNIVERSITY AGRICULTURAL EXPERIMENT STATION 


\section{NORTHEAST REGIONAL PUBLICATION}

Published for the State Agricultural Experiment Stations of Maine, Massachusetts, New Hampshire, Pennsylvania, Vermont, and West Virginia and for the Northeastern Forest Experiment Station, Forest Service, the United States Department of Agriculture. The research was conducted cooperatively by these agencies and was supported in part by regional funds provided under Title I, section 9b3, of the Bankhead-Jones Act, as amended August 14, 1946, authorizing cooperative research by state agricultural experiment stations and the Hatch Act, as amended August 11,1955 . This research was conducted under the Northeastern regional project, NEM-24, Marketing of Lumber in the Northeast.

West Virginia University Agricultural Experiment Station

College of Agriculture, Forfistry, and Home Economics A. H. Vanlandingham, Director 


\section{Marketing of Lumber Produced by Sawmills In the Northeast- Phase I}

by

Wallace W. Christensen

Henry H. Webster

Gregory Baker

Newell A. Norton

William H. Reid 



\section{THE NORTHEASTERN FOREST PRODUCTS MARKETING TECHNICAL COMMITTEE}

A. H. VanLandingham, Administrative Advisor West Virginia Agricultural Experiment Station

Wallace W. Christensen, ${ }^{*}$ Chairman West Virginia Agricultural Experiment Station

GREgORY BAKER

SAMUEL Brock

Maine Agricultural

Experiment Station

ROBERT S. BOND

Massachusetts Agricultural

Experiment Station

Oliver P. Wallace

New Hampshire Agricultural

Experiment Station

Newell A. Norton

Orvel A. Schmidt

Pennsylvania Agricultural

Experiment Station
Roy A. WhitMore

William R. Adams

Vermont Agricultural

Experiment Station

William H. Reid

Norman D. Jackson

West Virginia Agricultural

Experiment Station

Henry H. Webster

ROBERT FRANK

Northeastern Forest

Experiment Station

U. S. Forest Service

United States Department of

Agriculture

GlenN R. SMith

State Experiment Station Division

Agricultural Research Service

United States Department of Agriculture

*Now with Foresl Products Requirements Branch, Division of Forest Economics Research, U. S. Forest Service, U.S.D.A. 
Digitized by the Internet Archive in 2010 with funding from

Lyrasis Members and Sloan Foundation 


\section{Summary}

Northeastern Regional Marketing Project NEM 24, "Marketing of Lumber in the Northeast," is designed to describe the structure of lumber markets in the northeastern United States. It provides background information useful to lumber producers and to researchers evaluating possible changes in the structure of these markets. It is a joint project of the agricultural experiment stations of Maine, Massachusetts, New Hampshire, Pennsylvania, Vermont, and West Virginia, working in cooperation with the Northeastern Forest Experiment Station, U. S. Forest Service.

Phase I of NEM-24, which this bulletin covers, describes the products sold and the services provided by lumber manufacturers. Data for 1957 sales were obtained by means of personal interviews with lumber manufacturers selected from sawmill directories for the six participating states. Essentially-complete canvasses were carried out in some of the smaller states, and random sampling-after stratification by production class and geographic area-was employed in others. These data were compiled by cross classification and tabulation.

The product sold and the services provided by manufacturers have many attributes and are described in this bulletin. They range from the physical condition and source of the product to characteristics of the sale.

\section{CHARACTERISTICS OF THE LUMBER SOLD}

More than three-fourths of the hardwood lumber and 40 per cent of the softwood lumber was sold by manufacturers on a grade basis. More than one-half of the hardwood lumber and one-fourth of the softwood lumber sold on standard grades was of relatively high quality.

One-half of the softwood lumber, but only 10 per cent of the hardwood lumber, was sold in surfaced condition by passing through a planer. The balance was unsurfaced. Two-thirds of the hardwood lumber and one-half of the softwood lumber was either air- or kiln-dried before sale, and the remainder was sold in a "green" condition.

More than 90 per cent of the lumber sold by sawmill operators was manufactured in their own sawmills. The remaining 10 per cent was purchased for resale.

\section{CHANNELS OF DISTRIBUTION}

The channels of distribution for lumber produced by sawmills in the states studied, when rated according to volume of lumber movement, are: the wholesaler, the manufacturer of wood products, and the consumer, in that order. However, in the Allegheny region, which pre- 
dominates in hardwoods, the manufacturer is the principal outlet for lumber produced by sawmills.

The most important manufacturing outlets for softwood lumber produced in the region are wood container and miscellaneous products manufacturers, and the most important manufacturing outlet for hardwood lumber is the furniture manufacturer. Flooring and pallet manufacturers are also important outlets for hardwood lumber produced in the northeastern area.

\section{MARKET GEOGRAPHY}

The Northeastern Region is its own best lumber market. With the exception of West Virginia, all of the states sold less than 10 per cent of their total lumber volume outside the region.

Lumber exports from each of the northern New England states moved mainly into the Massachusetts-Connecticut area. In the Allegheny region, lumber exports were much more dispersed-Pennsylvania exported lumber to 15 states, and West Virginia exported to 18 states. Graded lumber made up a larger proportion of total export volume than was the case of lumber sold to in-state outlets.

\section{MARKETING PRACTICE}

Small lumber producers attract the attention of relatively few potential buyers, while large producers attract a greater number of potential buyers. The large producers are in a better position to explore alternate markets.

Throughout the region the cash sale, requiring payment within 30 days, is the predominate term of payment. More than 90 per cent of the lumber is marketed by cash sales. The principal sales agreement is the renewable agreement for a specified quantity of lumber with the agreement renewable when the quantity has been delivered.

Two-thirds of the lumber volume was sold on the basis of seller's measurement and the remainder on buyer's measurement. However, almost one-half of the lumber sold by the small mill operators was measured by the buyer, whereas only 14 per cent of that sold by the large mills was so measured.

While many reasons were given by the operators for selling to particular buyers, "established reliability of the buyer" assumed major importance, whether based on prompt payment, long-standing business connection, or buyer's reputation.

\section{PRICING IN THE LUMBER MARKET}

Average F.O.B. mill price per MBF for rough, air-dried lumber dropped with decreasing size of operation. This correlation of average 
price and mill-size class apparently stems from the fact that marketing handicaps become more severe with decreasing scale of operation.

Average price throughout the region for quality grade lumber (\#1 Common and Better hardwood, \#2 Common and Better softwood) was more than twice that of ungraded lumber-emphasizing the importance of producing and marketing lumber for maximum grade yield.

A universal problem was that of profitably handling lumber in the lower standard grades-\#2 Common and Poorer for hardwoods and \#3 Common and Poorer for softwoods. With average prices of low-grade lumber being about equal to those of ungraded lumber, some mill owners market their entire output on a mill-run basis. By this process, potential revenue is lost, since total output will usually include a certain proportion of quality grade lumber. 


\section{Marketing of Lumber* Produced By Sawmills In The Northeast-Phase I}

WALLACE W. CHRISTENSEN, HENRY H. WEBSTER, GREGORY BAKER, Introduction NEWELL A. NORTON, and WILLIAM H. REID

I UMBER manufacturers have to make decisions, and, in the process, they are faced with choices. In selling lumber they have to decide the form of product they will sell; to whom they will sell; at what stage of delivery they will sell; the volumes they will sell; the size of shipments they will sell; the conditions of sale they will specify; the prices they will ask; and so on.

Decisions are also made when changes are contemplated. What specific changes in the type of product sold and the services provided by lumber manufacturers will increase their profits? What changes that manufacturers might make in the structure of lumber markets will reduce the cost of "converting" lumber at the sawmill into lumber in the hands of users at their plants or building sites? (By "changes in market structure" we mean changes in the roles played by lumber manufacturers, lumber users, and market intermediaries.) These are key questions from the viewpoint of lumber manufacturers.

These types of decisions are important because they affect the profits earned by lumber manufacturers and the products available to the lumber users. Indirectly, through these profits and their affects on procurement policies, they also affect land management. These affects are important, too, as roughly half the timber cut both nationally and in the Northeast is used in the manufacture of lumber. ${ }^{1}$

Forest products marketing research can provide lumber manufacturers with information useful in making decisions. Such research will eventually provide information useful in evaluating specific changes in the products sold and in the services provided by the lumber manufacturers. Eventually it will provide information useful in evaluating specific changes in the structure of lumber markets. These changes might be best evaluated in terms of the immediate costs of making them and the cost-savings ultimately resulting from them.

*The standard definition for lumber is qualified for this report to include only softwood lumber four inches or less and hardwood six inches or less in the least dimension, and eight feet or more in length. Mine material, industrial blocking, and ties are not included.

${ }^{1}$ U.S. Forest Service. Timber Resources for America's Future. Forest Resource Report No. 14, 1958 . 
Such evaluations are a goal for forest products marketing research. They can be approached only gradually, however, because researchers currently do not have sufficient information to specify the alternatives open to lumber manufacturers. To specify such alternatives, researchers must understand current lumber-marketing practices-products sold and services provided by lumber manufacturers, products purchased and services sought by lumber users, and the product transformations performed and services provided by market intermediaries. And knowledge of this kind is indeed fragmentary. ${ }^{2}$

To provide this kind of knowledge for the Northeast, the agricultural experiment stations of Maine, Massachusetts, New Hampshire, Pennsylvania, Vermont, and West Virginia, in cooperation with the Northeastern Forest Experiment Station of the U. S. Forest Service, have undertaken Northeastern Regional Marketing Project NEM-24.

Viewed in broad perspective, this project is designed to compare the product sold and the services provided by lumber manufacturers, in selected sections of the Northeast, with the product purchased and the services sought by lumber users. To meet this objective, the project is divided into three phases.

Phase I is a study of the product sold and the services provided by lumber manufacturers. Phase II is a study of the product purchased and of services sought by industrial lumber users (flooring plants, furniture plants, etc.) . Phase III is a study of purchase, transformation, and sale of lumber by retailers, including the services sought and rendered.

This bulletin is a report on Phase I. It is an attempt to examine the products sold and the services provided by northeastern lumber manufacturers in terms of 16 different characteristics. These characteristics range from physical attributes of the product, such as species, quality, seasoning, finish, etc., to characteristics of the sale, such as sales method, and terms of sale.

\section{Research Procedure}

Lumber manufacturers listed in sawmill directories for Maine, Massachusetts, New Hampshire, Pennsylvania, Vermont, and West Virginia constituted the population sampled. The sampling procedure varied somewhat from state to state because of differences in mill-size class groupings in the various directories and because of variances in the size of the sawmill industry from one state to another.

In some of the smaller states, essentially complete canvasses of lumber manufacturers were carried out. In other states, stratified random sampling was used, with stratification based on mill production

${ }^{2} \mathrm{G}$.
$458,1957$. 
class and geographic area. Data were obtained from 677 mills in the six participating states. These clata were secured from the lumber manufacturers by means of personal interviews.

Data from questionnaires were compiled and analyzed by cross classification and tabulation, using McBee Keysort cards. All summaries were prepared at the state level. Formal regional summaries were not prepared, because of the variation in sampling method and intensity from state to state. However, an informal combination of state data was made for this report, using weights derived from earlier lumber production canvasses. ${ }^{3}$

\section{Characteristics of Lumber Sold by Northeastern Manufacturers}

For purposes of analysis in this report, the six states participating in this study have been divided into two regions. Maine, Massachusetts, New Hampshire, and Vermont will be referred to as the "northern New England" region. Pennsylvania and West Virginia will be referred to as the "Allegheny" region.

\section{SPECIES}

Northern New England and the Allegheny regions are more than geographic areas. They differ widely in terms of lumber sold by lumber manufacturers. The northern New England region is primarily a softwood area, and the Allegheny region is overwhelmingly a hardwood area, as indicated in Figure 1.

There are differences within the major species groups. White pine is the major softwood lumber species in northern New England, whereas hemlock makes up a large portion of the limited softwoods sold by lumber manufacturers in the Allegheny region (Figure 2). Oaks and yellow poplar are major hardwood species in the Allegheny region, and maple and birch are predominant among the hardwoods of the northern New England region (Figure 3).

\section{CONDITION}

Lumber can be sold either rough or dressed, either green or dried. Data obtained in this study show that lumber manufacturers in the northern New England and the Allegheny regions sold more than half of their softwood in dressed condition (Figure 4). By contrast, about 90 per cent of the hardwood lumber was sold in rough condition.

This difference reflects the differing end use requirements for the two species classes. Softwood lumber is used primarily in construction, and undergoes no significant change in form, while hardwood lumber is

${ }^{3}$ Steer, Henry B. Lumber Production in the United States, 1799-1946. U. S. Dept. of Agriculture Misc. Pub. 669, 233 pp., 1948. 
NORTHERN NEW ENGLAND SALES

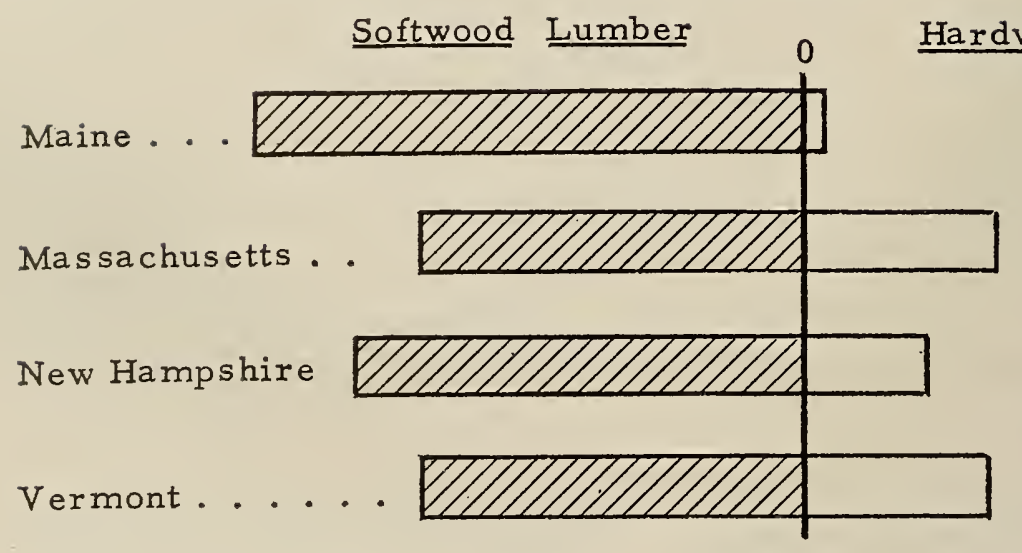

ALLEGHENY REGION SALES

Softwood Lumber Hardwood Lumber

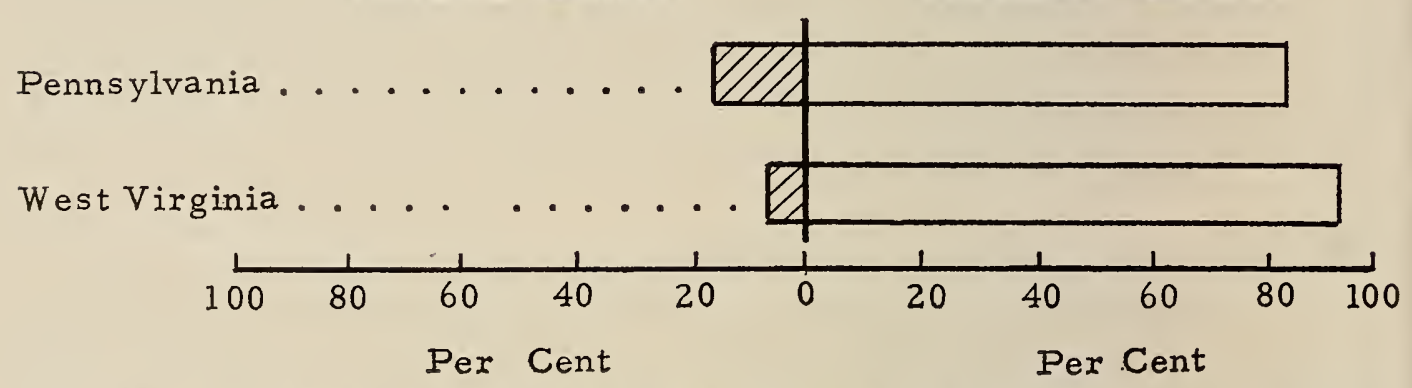

FIGURE 1. Percentages, by states, of hardwood and softwood lumber marketed by lumber manufacturers.

used in the manufacture of furniture, flooring, etc., and thus undergoes considerable change in form.

About two-thirds of the softwood lumber and roughly one-half of the hardwood lumber was either air- or kiln-dried before sale, as shown in Figures 5 and 6 . The remainder was sold green. Drying, particularly kiln drying, was concentrated in areas having large mills. Thus Maine, West Virginia, and New Hampshire led in the sale of dried lumber.

\section{GRADE}

The quality of lumber ranges widely; so do methods for recognizing quality. In 1957 about 40 per cent of the softwood lumber and more than 80 per cent of the hardwood lumber sold by lumber manufacturers in the northern New England and the Allegheny regions was sold on a graded basis.

Grading and use of st:ndard grades was most common at large mills in major production areas. For example, Maine was a leader in the sale of softwood lumber on a graded basis, while Pennsylvania and West Virginia led in sales of graded hardwood lumber, as shown in Figure 7. 
NORTHERN NEW ENGLAND- SOFTWOODS

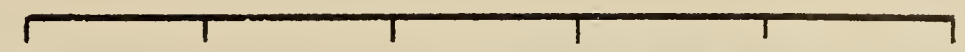

Maine..... $\square$

Massachusetts.

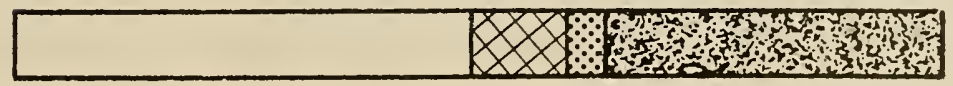

New Hampshire.

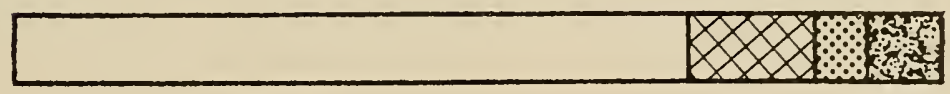

Vermont ....

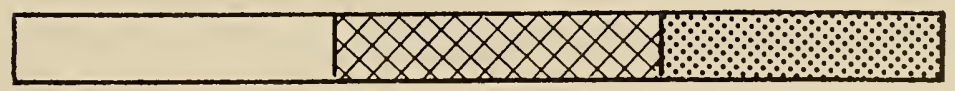

ALLEGHENY REGION-SOFTWOODS

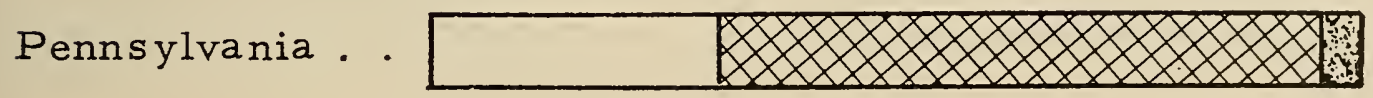

West Virginia.
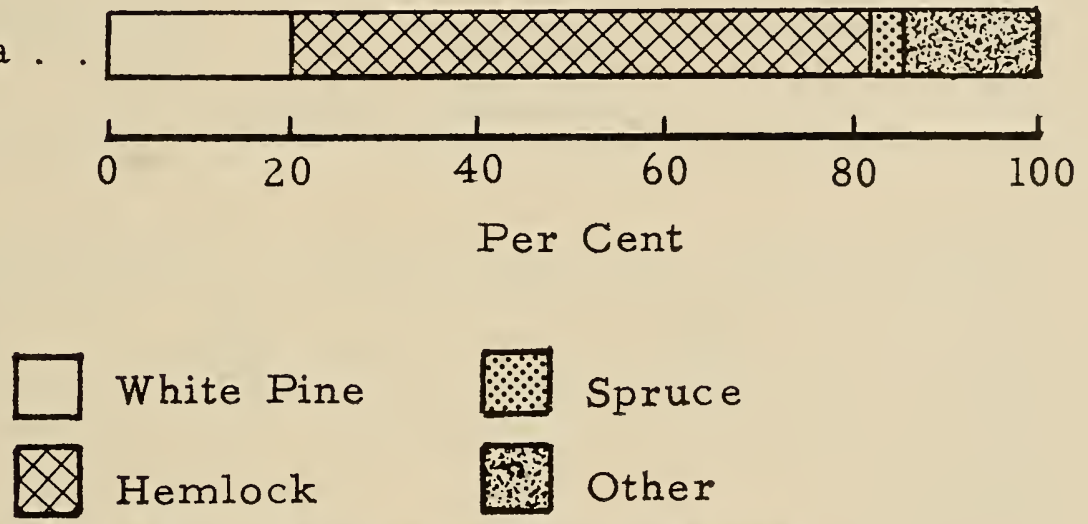

Figure 2. Percentages of softwood species marketed, by states.

Although lumber grades are complex, they can be meaningfully simplified. Two grade classes can be defined-high quality and low quality. For present purposes, "high quality" will be considered to include grades \#l Common and Better in hardwoods (furniture quality), and \#2 Common and Better in softwoods (structural and finish quality). Conversely, "low quality" consists of grades \#2 Common and Poorer in hardwoods and \#3 Common and Poorer in softwoods.

By these definitions, somewhat more than half of the hardwood lumber and roughly one-fourth of the softwood lumber sold in standard grades was high quality, as shown in Figures 8 and 9. There were no outstanding differences between the two areas in terms of hardwood quality. Softwood quality appeared to be better in the Allegheny region, but this difference is probably insignificant. 
Maine

Massachusetts.

New Hampshire.

Vermont...
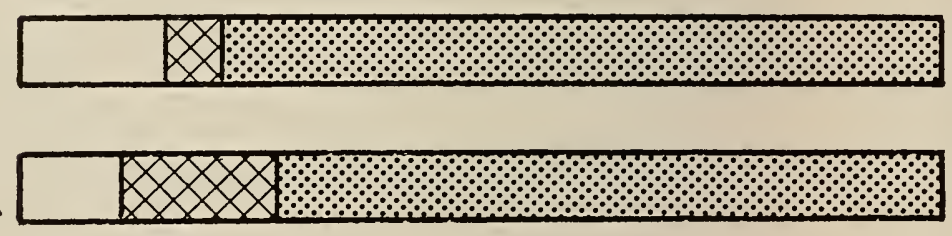

ALLEGHENY REGION-HARDWOODS

Penns ylvania. .

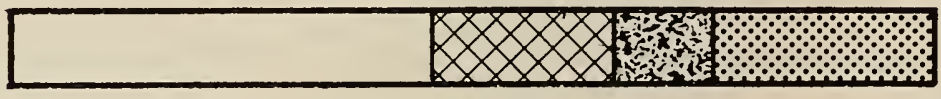

West Virginia. .

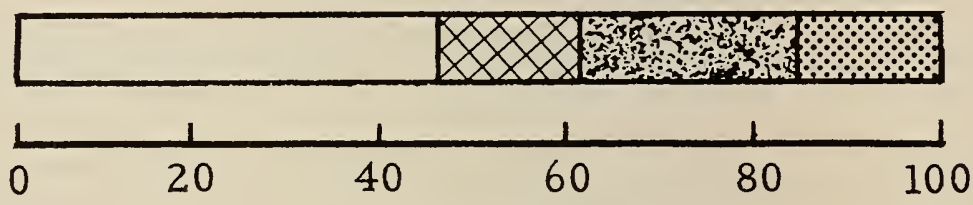

Per Cent

$\square$ Oak $\bigotimes$ Maple-Birch Y-Poplar Other

Figure 3. Percentages of hardwood species marketed, by states.

\section{SOURCE}

Where does lumber sold by lumber manufacturers in northern New England and the Allegheny regions come from? In 1957, approximately 90 per cent of it was produced by the manufacturers in their own sawmills, as indicated in Figure 10. The remaining 10 per cent was purchased from other manufacturers and then resold. Hence, establishments commonly classified as lumber manufacturers can play two roles-that of manufacturer and that of concentrator.

Most of the concentration of lumber is done by large establishments. ${ }^{4}$ About one-fourth of the lumber sold by large sawmills was purchased from other manufacturers. Only very minor quantities sold by smaller sawmills were purchased from other manufacturers.

${ }^{4}$ Size classes used in this analysis are: Small mills-marketing from 1 MBF to 499 MBF annually; Medium mills-marketing from $500 \mathrm{MBF}$ to $3,000 \mathrm{MBF}$ annually; Large millsmarketing over 3,000 MBF annually. Average volumes marketed during 1957 for all sample mills in each size class were: Small mills-167 MBF; Medium mills-1,134 MBF; Large mills-5,957 MBBF. 


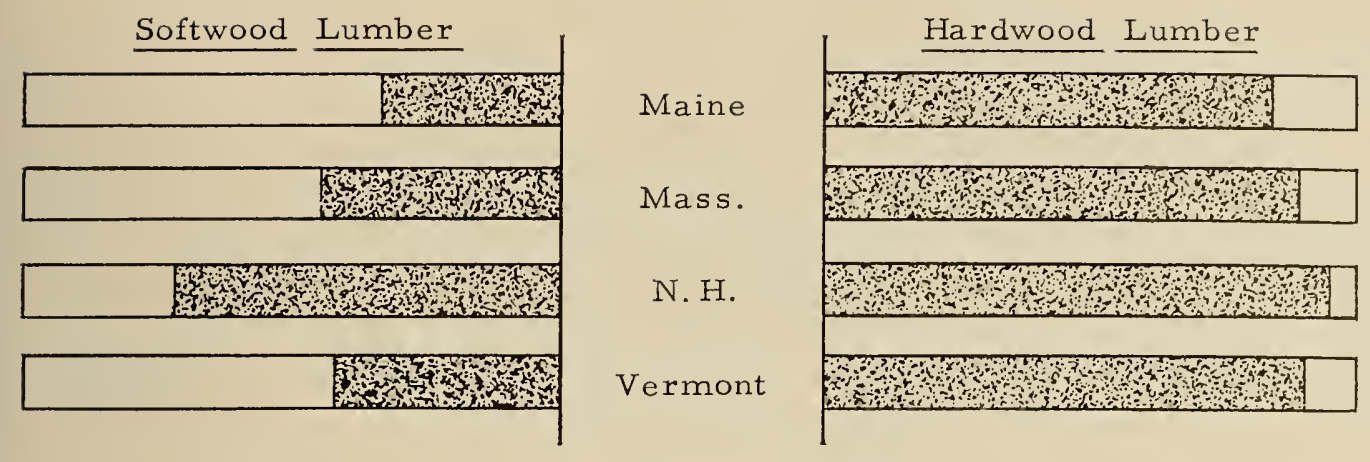

ALIEGHENY REGION

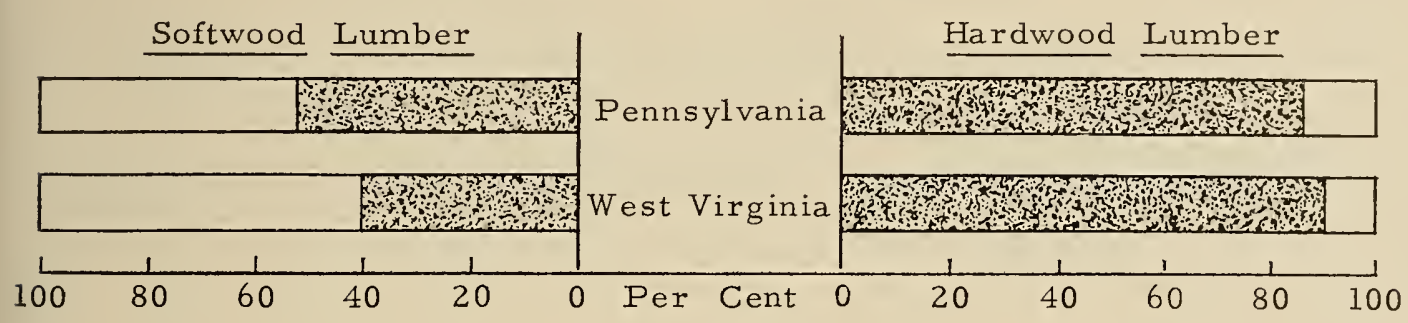

\section{$\square$ Dressed Rough}

Figure 4. Surface condition of softwood and hardwood lumber marketed, by states.

\section{Channels of Distribution in the Northeastern Lumber Market}

For purposes of this study, the channels of distribution, or outlets, used by the sawmill industry were divided into the following five classes:

Wholesaler-Purchaser who acquires lumber for subsequent resale to other distributors or manufacturers.

Retailer-Purchaser who acquires lumber for subsequent sale to consumers.

Manufacturer-Purchaser who acquires lumber for subsequent manufacture into producers' or consumers' goods.

Consumer-Purchaser who acquires lumber for the satisfaction of individual needs. No further sale is involved.

Other-Brokers, commission agents, and jobbers. These specialized operators may bridge the gap between the lumber producer and any other outlet, but they normally do not take title to the goods being moved.

\section{MARKET OUTLETS FOR HARDWOOD LUMBER}

The manufacturing outlet absorbed the largest proportion of hardwood lumber marketed by lumber producers in four of the six states 


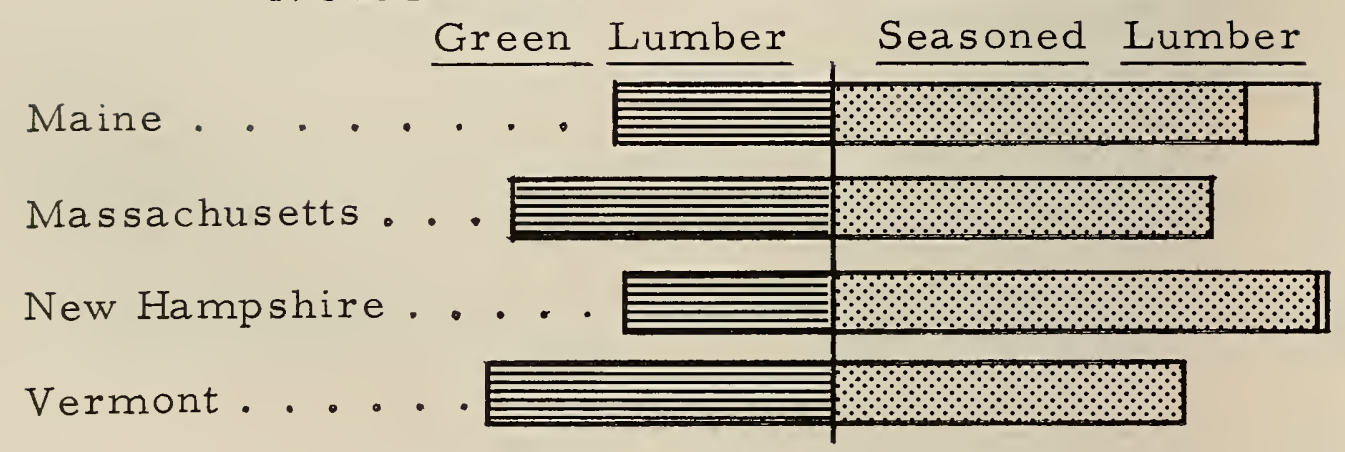

ALLEGHENY REGION
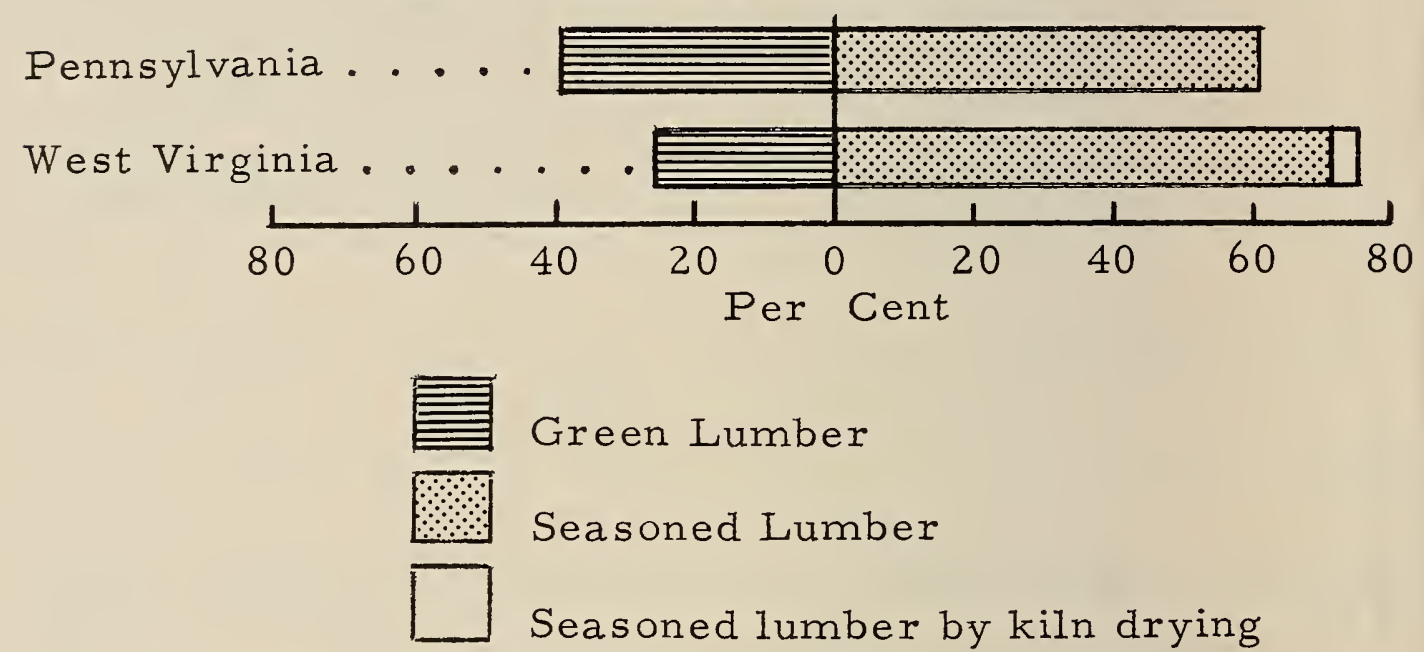

Green Lumber

Seasoned Lumber

Seasoned lumber by kiln drying

Figure 5. Moisture condition of softwood lumber marketed, by states.

involved in this study. New Hampshire and Maine were the exceptions. They sold their hardwood lumber mainly to wholesalers, as indicated in Figure 11.

In the Allegheny region, oak was the principal species sold in all outlets, comprising more than 60 per cent of all lumber marketed to consumers and about 40 per cent of the lumber sold in each of the other outlets (Figure 12).

Species of lumber sold in the northern New England region exhibited more variation among types of outlets than was found in the Allegheny region. For example, maple and birch represented about 50 per cent of all lumber sold to the manufacturer and "other" outlets, while in the retail outlet, oak and "other species" accounted for 82 per cent of lumber sales. In the wholesale and consumer outlets, the "other" species of lumber represented the largest proportion of sales volume. 

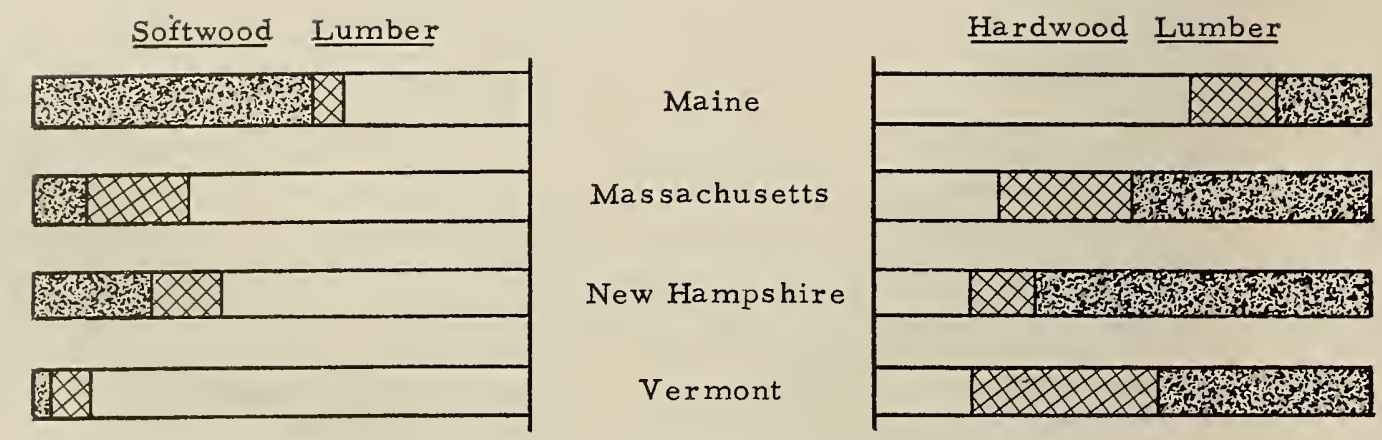

ALLEGHENY REGION
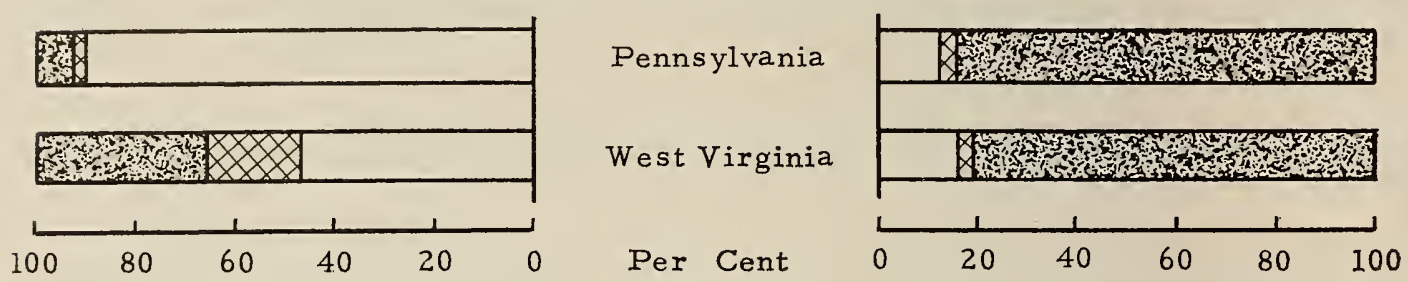

Std. Lumber Grades Othex

Nongraded

Figure 7. Grading practices, by states, based on percentage of lumber marketed.

than one-half of the hardwood lumber sold to wholesalers, about threefourths of that marketed to retailers, and approximately one-half of that going to the "other" type of outlet (broker, commission agents, and jobbers) was of high quality. This is shown in Figure 15. In contrast, about two-fifths of the hardwood lumber marketed to manufacturers and one-tenth of that sold to consumers was of high quality.

The amount of high quality softwood lumber marketed was negligible, and did not exceed 3 per cent of total volumes sold in any market outlet. As shown in Figure 16, ungraded softwood lumber made up the largest proportion of sales in all outlets, accounting for about 80 per cent of total sales volume to the retailer, consumer, and "other" outlets, and about 60 per cent in the wholesaler and manufacturer outlets.

\section{TYPES OF MANUFACTURING OUTLETS USED}

For this study, the manufacturing outlet was subdivided into the nine categories listed in Table 1. As indicated, the proportions marketed to manufacturers differed between species classes and between regions in each species class.

Softwood lumber marketed in the manufacturing outlet was sold by lumber producers in the northern New England region principally to fabricators of wood containers. In the Allegheny region, manufacturers of furniture, wood containers, and prefabricated products were the major purchasers. 
Table 1. Percentage Distribution of Lumber Marketed By Type of Manufacturing Outlet, Species Class, and Region (Per Cent of Volume Sold in Manufacturing Outlet)

\begin{tabular}{|c|c|c|c|c|}
\hline \multirow{2}{*}{$\begin{array}{c}\text { MANUFACTURLNG } \\
\text { OUTLET }\end{array}$} & \multicolumn{2}{|c|}{ HARDWOOD LUMBER } & \multicolumn{2}{|c|}{ SOF'TWOOD LUMBER } \\
\hline & ALLEGHENY & $\begin{array}{c}\text { NORTHERN } \\
\text { NEW ENGLAND }\end{array}$ & ALLEGHENY & $\begin{array}{c}\text { Northere } \\
\text { NEW ENGLAND }\end{array}$ \\
\hline 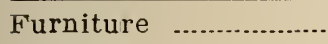 & 44 & 37 & 21 & 3 \\
\hline Flooring & 26 & 6 & 0 & 0 \\
\hline Turnings & 1 & 7 & 6 & 0 \\
\hline Small dimension ........ & 2 & 7 & 0 & 0 \\
\hline Wood containers ...... & 4 & 7 & 28 & 51 \\
\hline General millwork .... & 6 & 1 & $*$ & 7 \\
\hline Pre-fabrication ....... & $*$ & 0 & 18 & 7 \\
\hline Pallet & 10 & 20 & 5 & 4 \\
\hline Other .......... & 7 & 15 & 22 & 28 \\
\hline
\end{tabular}

*Less than .5 of 1 per cent.

SOFTWOOD L UMBER

NORTHERN NEW ENGLAND

The Better Grades 0 The Poorer Grades

Maine.........

Massachusetts ......

New Hampshire.......

Vermont.........

A L LEGHEN Y REGION

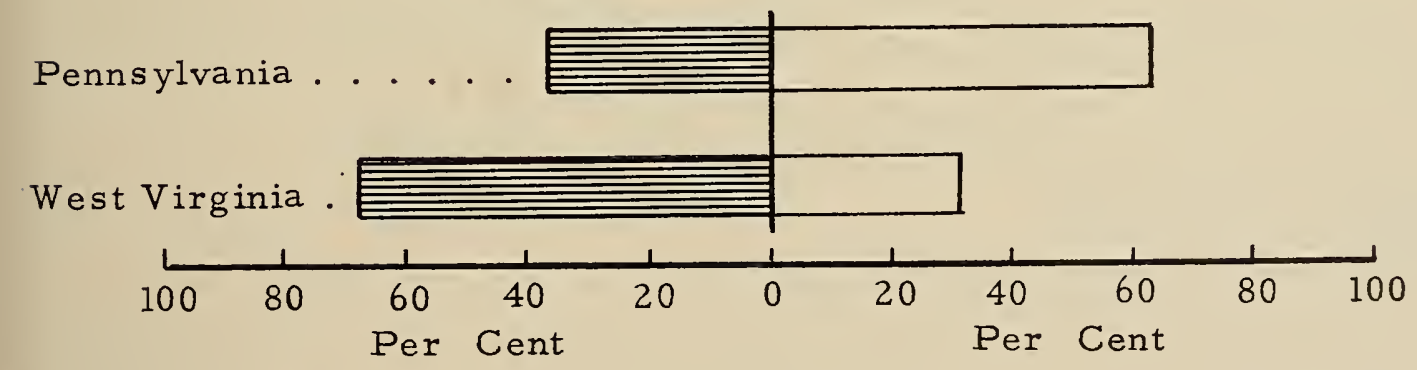

Better Grades ( $\# 2$ Common and Better)

Poorer Grades (\#3 Common and Poorer)

Figure 8. Percentages of softwood lumber marketed, by grades and by states. 
HARDWOOD L UMBER

NORTHERN NEW ENGLAND

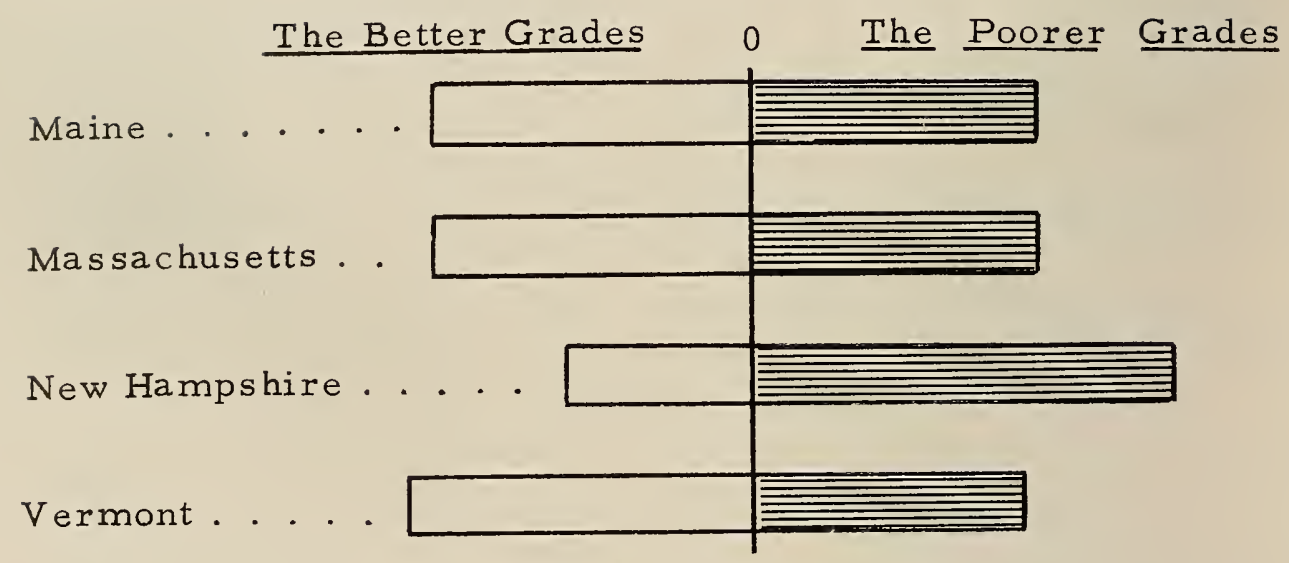

ALLEGHENY REGION

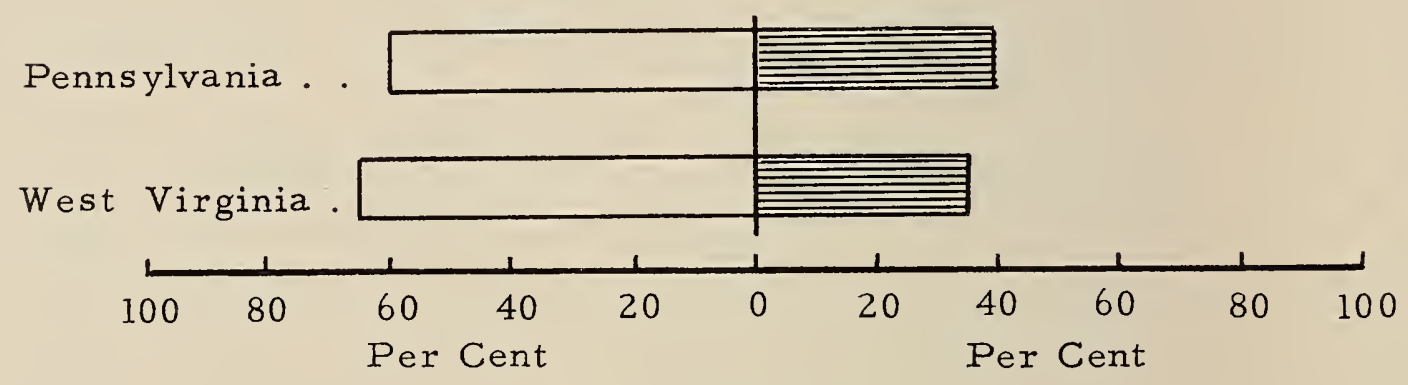

$\square$ Better Grades (\#l Common and Better)

Poorer Grades (\#2 Common and Poorer)

Figure 9. Percentages of hardwood lumber marketed, by grades and by states.

In the northern New England region, hardwood lumber marketed in the manufacturing outlet was sold mainly to manufacturers of furniture and pallets; while in the Allegheny region, fabricators of furniture and flooring were the main buyers of hardwood lumber in the manufacturing outlet (Figure 17).

\section{Market Geography \\ REGIONAL LUMBER MOVEMENT}

Geographical movement of lumber produced in the states involved in this study indicates that the northeastern region is its own best market. Less than one-tenth of all lumber marketed by the northern New England states and Pennsylvania moved into markets outside the region. West Virginia was the exception, distributing almost one-half of its sales volume to states outside of the region, as reflected in Figure 18. 
Lumber Produced In:

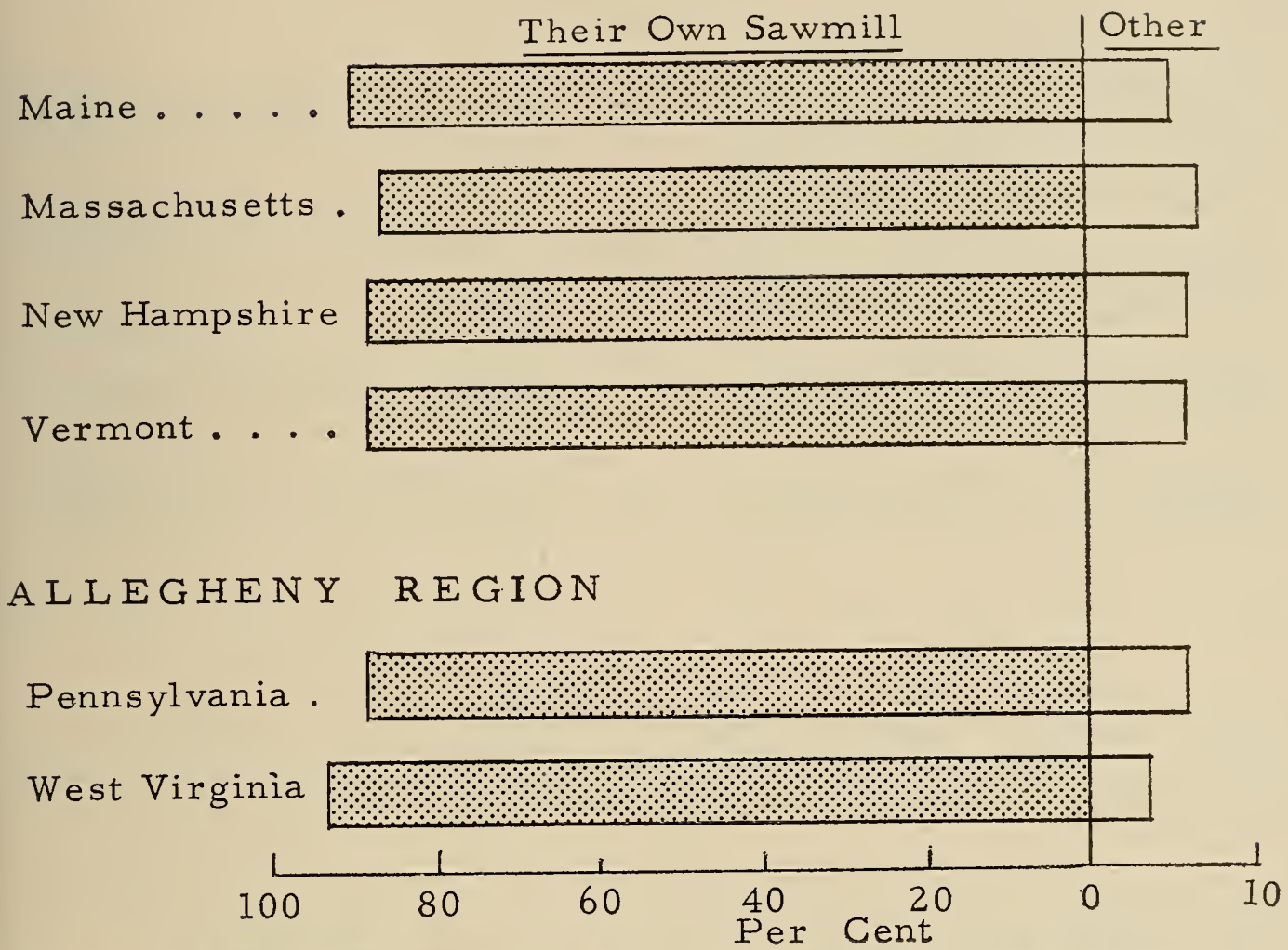

Figure 10. Percentages of lumber marketed by sawmill owners, by source and by states.

New Hampshire

Maine

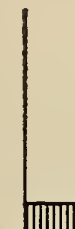

Rest of Region

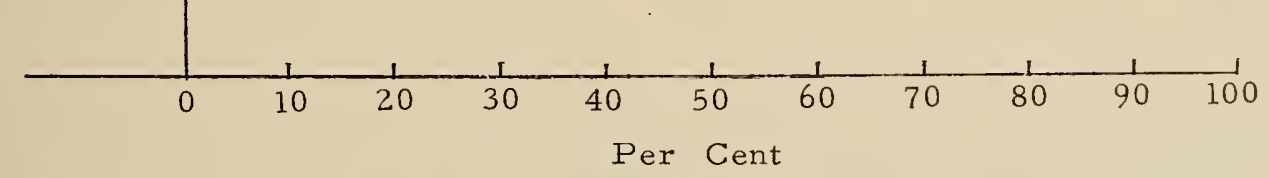

|nIIIII Wholesaler $\square$ Retailer

Other

Figure 11. Percentage distribution of hardwood lumber sold, by type of market outlet. 


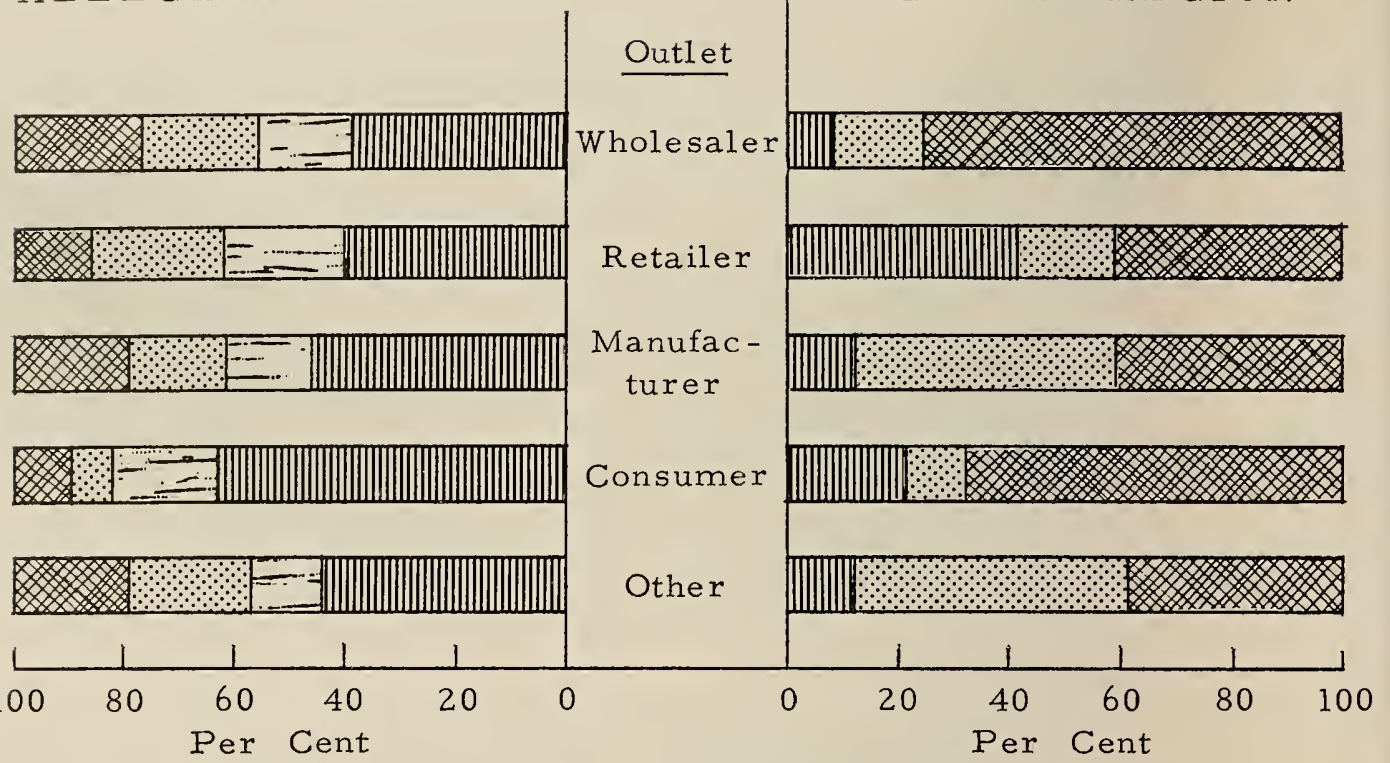

\section{Maple Birch Yellow Poplar}

Figure 12. Percentage distribution of hardwood lumber sold, by species, outlet, and region.

*Varying mixtures of cherry, beech, ash, elm, walnut, hickory, and other miscellaneous hardwoods.
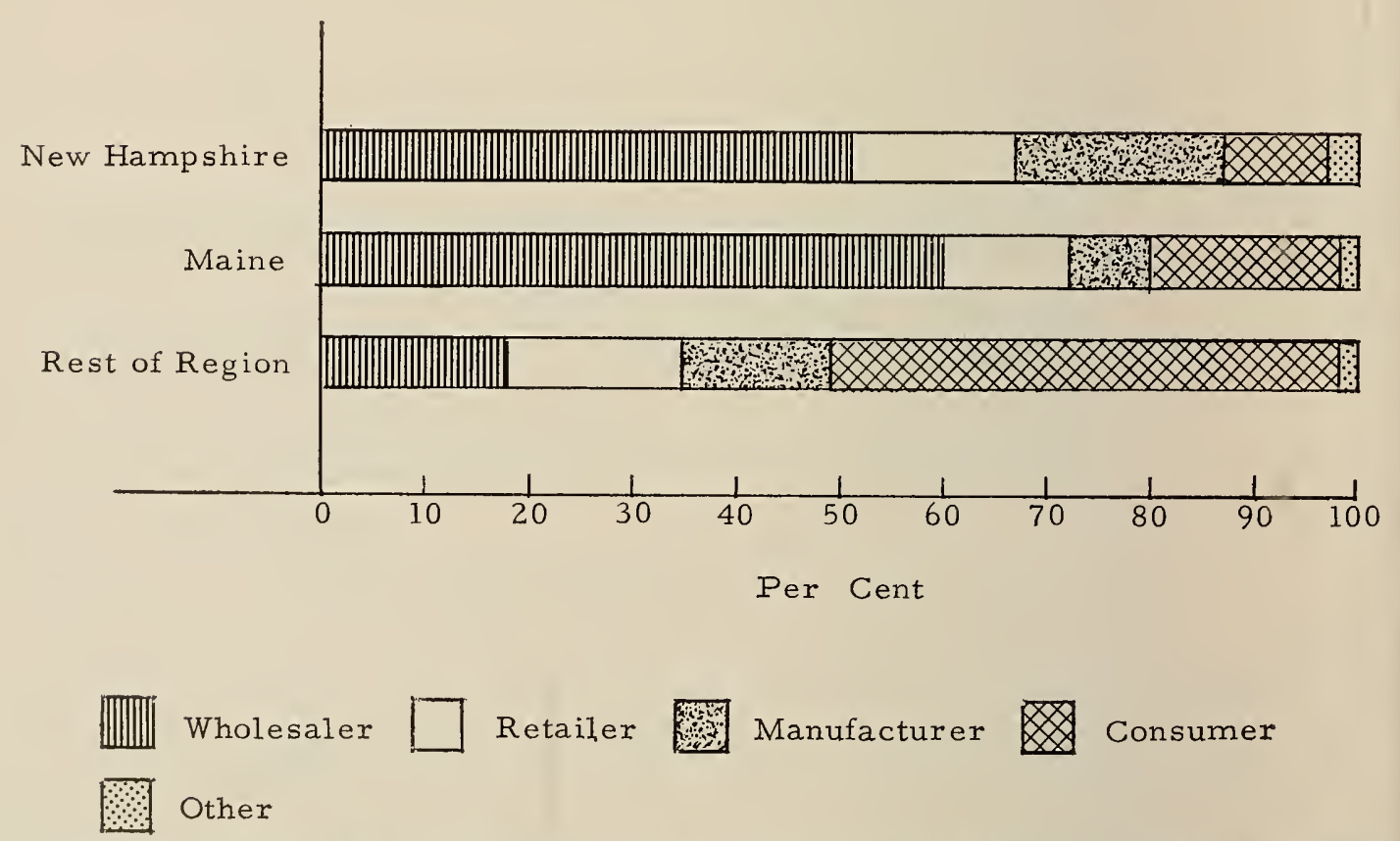

Figure 13. Percentage distribution of softwood lumber sold, by type of market outlet. 


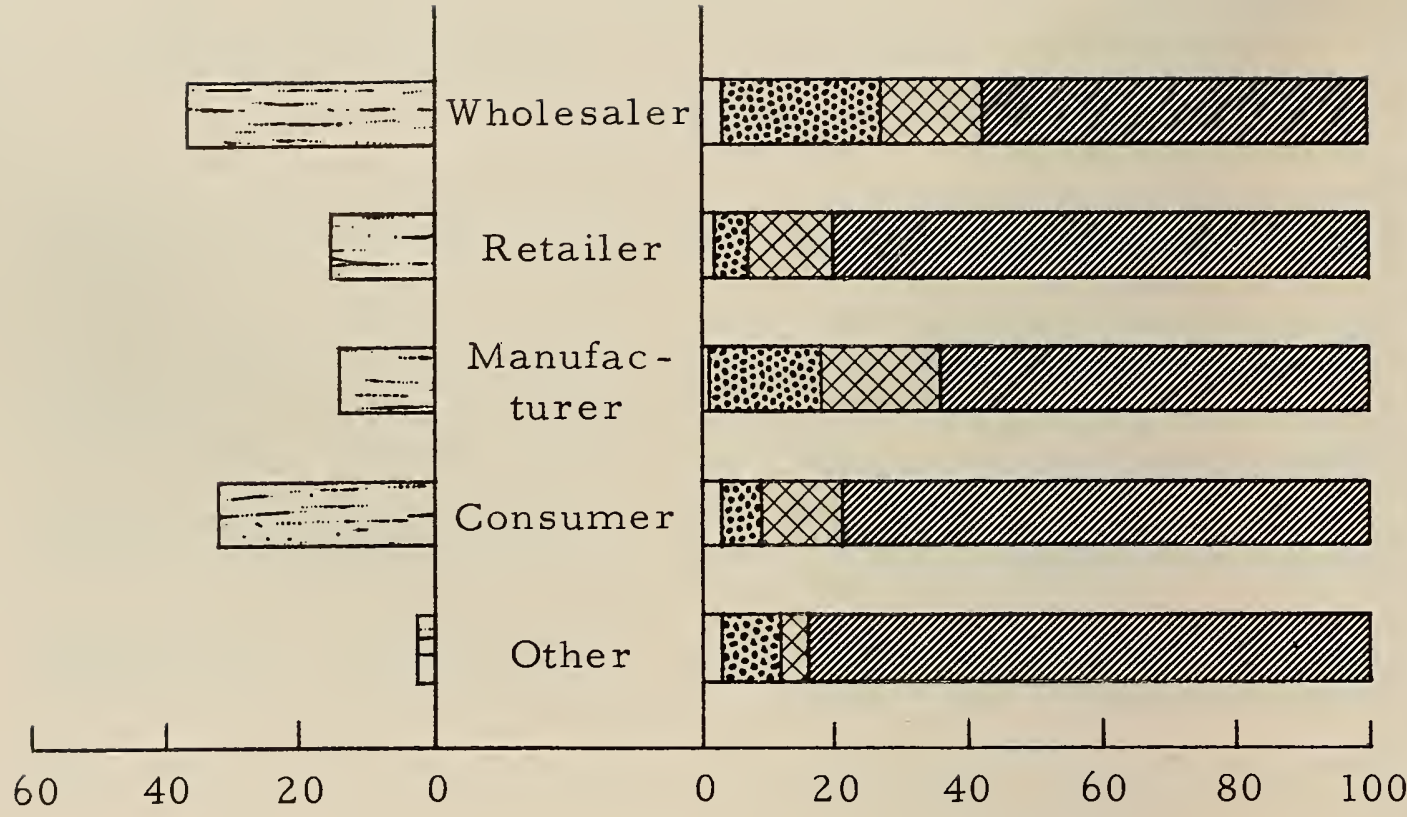

Per Cent of All Softwood Lumber Marketed, by Outlet

2 Common \& Better

3 Common \& Poorer

Other

Ungraded

Figure 16. Percentage distribution of softwood lumber marketed, by outlet and grade.

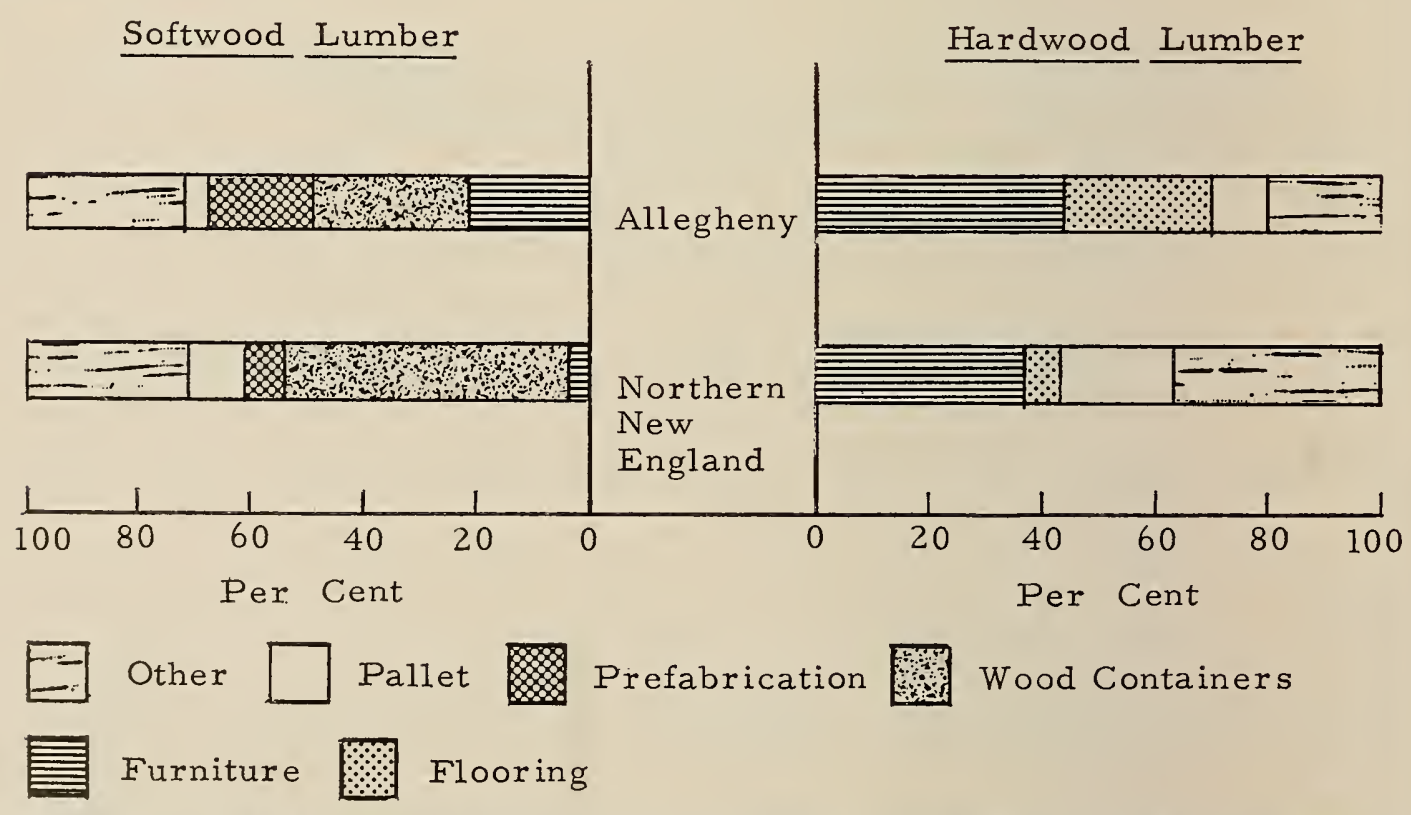

Figure 17. Percentage distribution of lumber marketed, by major types of manufacturing outlets, species class, and region. 


\section{NORTHERN NEW ENGLAND REGION}

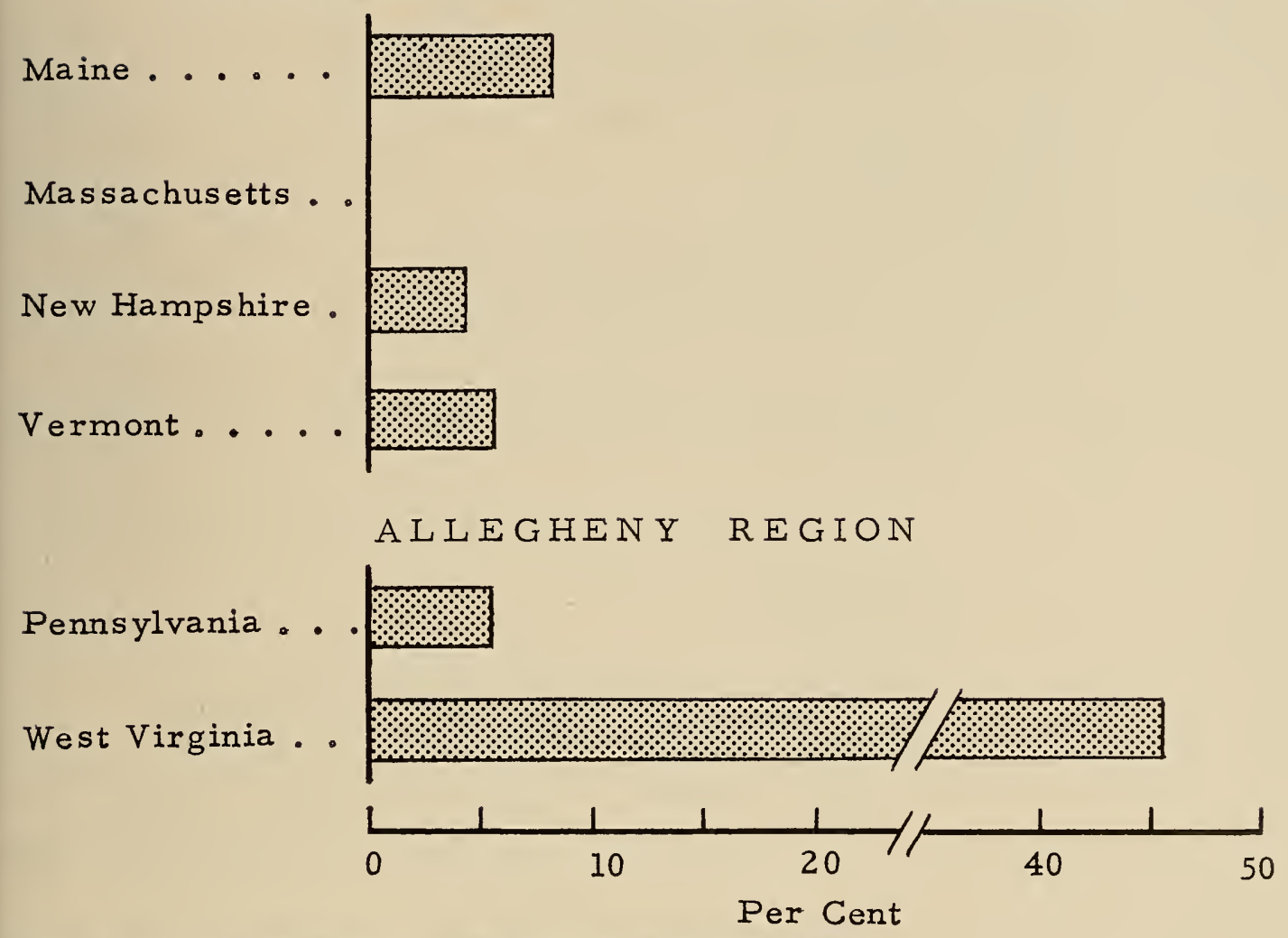

Figure 18. Out-of-region lumber movement by states.

(percentages are proportions of total lumber volume marketed)

That West Virginia should differ from other states in the study area is as might be expected, considering its location at the southern extremity of the region. It is close to the South Atlantic and the Central States regions, which contain excellent markets for hardwood lumber. 'The furniture industry of North Carolina and Virginia and the millwork, flooring, furniture, and pallet industries in Ohio all attract hardwood lumber from West Virginia.

\section{OUT-OF-STATE LUMBER MOVEMENT}

In contrast to the regional picture, most of the states are not their own best markets. As reflected in Figure 19, about one-half or more of the lumber produced in Maine, New Hampshire, Vermont and West Virginia was exported for processing or use elsewhere. Of these states, West Virginia was the major exporter, distributing slightly more than two-thirds of its production to out-of-state outlets.

The more heavily industrialized states of Pennsylvania and Massachusetts differed notably from others in the region-these states sold about 85 per cent of their production to markets within their borders. 


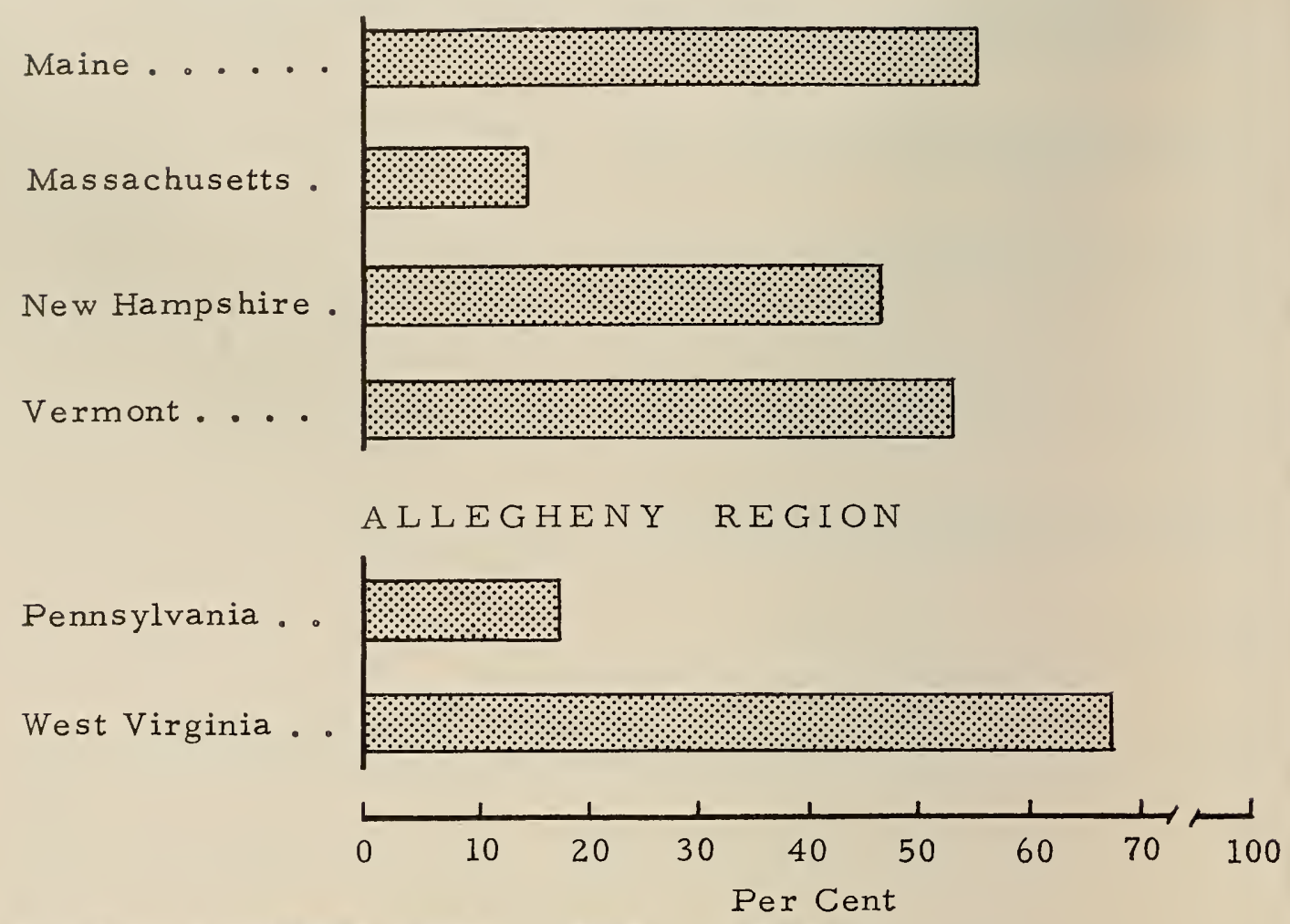

Figure 19. Out-of-state lumber movement by states.

(percentages are proportions of total lumber volume marketed)

In each state, a strong correlation exists between size-class of mill and the proportion of total volume exported. Small mills tend to market the major share of their total production to in-state markets. As millsize class becomes larger, the tendency is to export a larger share of annual production.

The cause of this pattern seems to hinge largely on the facts that (I) large mills are generally better informed than smaller mills regarding the over-all market situation and existing market alternatives, and (2) large out-of-state buyers are usually interested only in mills of a size capable of quickly supplying largc-volume orders. The second situation buttresses the first.

The net result is that small mills cannot compete successfully with larger ones for export markets. Therefore, their product moves mainly to available in-state markets.

\section{LUMBER EXPORT DESTINATION}

The geographic destination of lumber exports from the northern New England region presents a pattern considerably different from that of the Allegheny region, as shown in Figures 20 through 25. Northern New England region lumber exports are directed mainly to the 


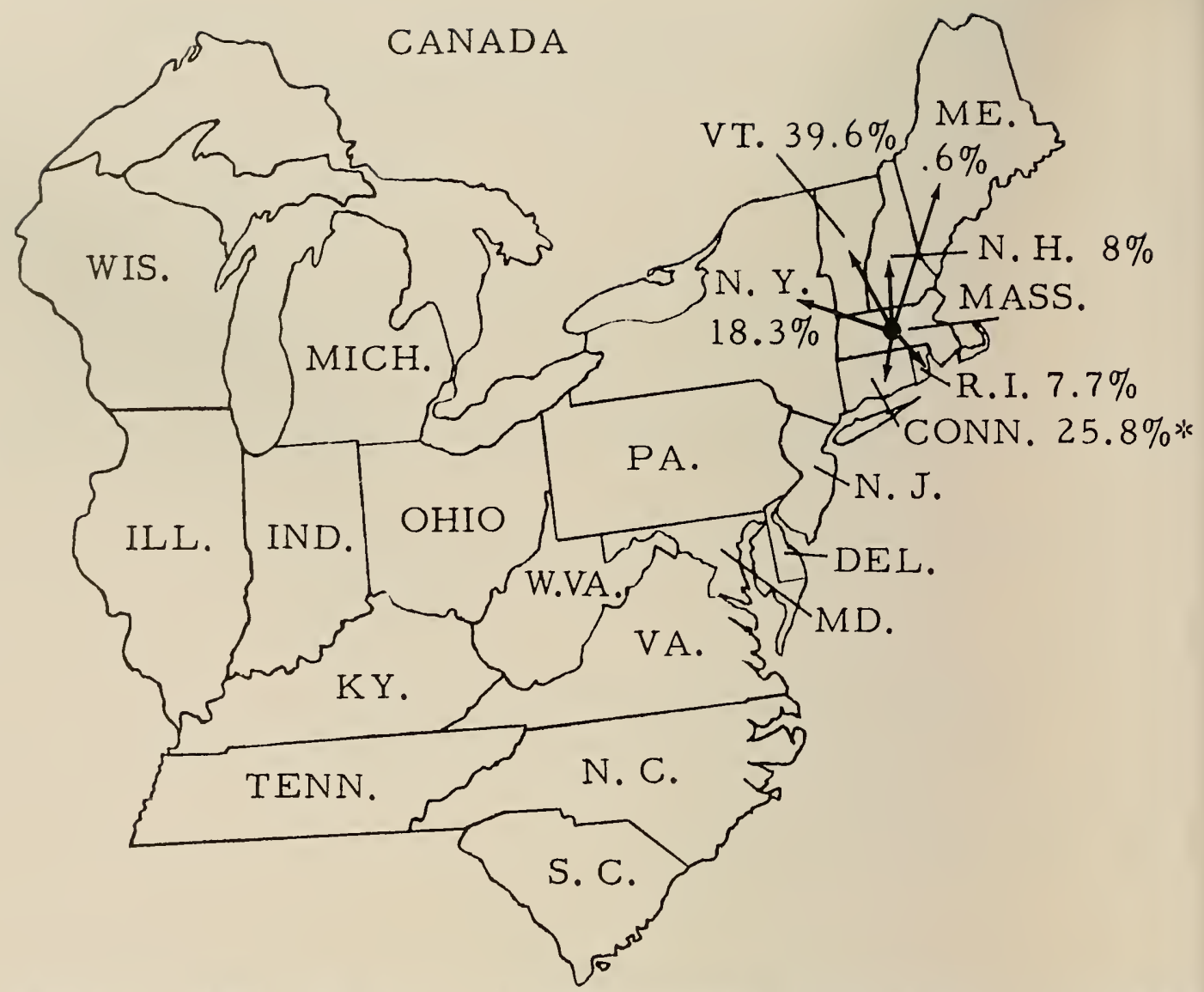

Figure 21. State destination of Massachusetts lumber sold to out-of-state outlets.

*Percentages are proportions of total lumber volume exported from Massachusetts.

lets. The destination of these grade-lumber exports followed somewhat the distribution discussed in the preceding section. As with all-lumber exports, the northern New England region is its own best market for grade-lumber exports.

Massachusetts and Connecticut, as with the case of all-lumber exports, absorbed the major share of the grade-lumber export volume from the other states in that area. While Massachusetts was the leading importer of all-lumber exports, Connecticut led in the importing of graded softwood lumber. For example, Vermont, Massachusetts, New Hampshire, and Maine sold about one-half of their graded softwood lumber to Connecticut and one-third to Massachusetts. For graded hardwood lumber, Massachusetts was the major importer.

In the Allegheny region the distribution of grade-lumber exports closely paralleled that of the all-lumber exports. Species-class in this region did not alter the situation, as it did to some degree in New England, since roughly nine-tenths of the lumber marketed by Pennsylvania and West Virginia is hardwood lumber. Moreover, the softwood 


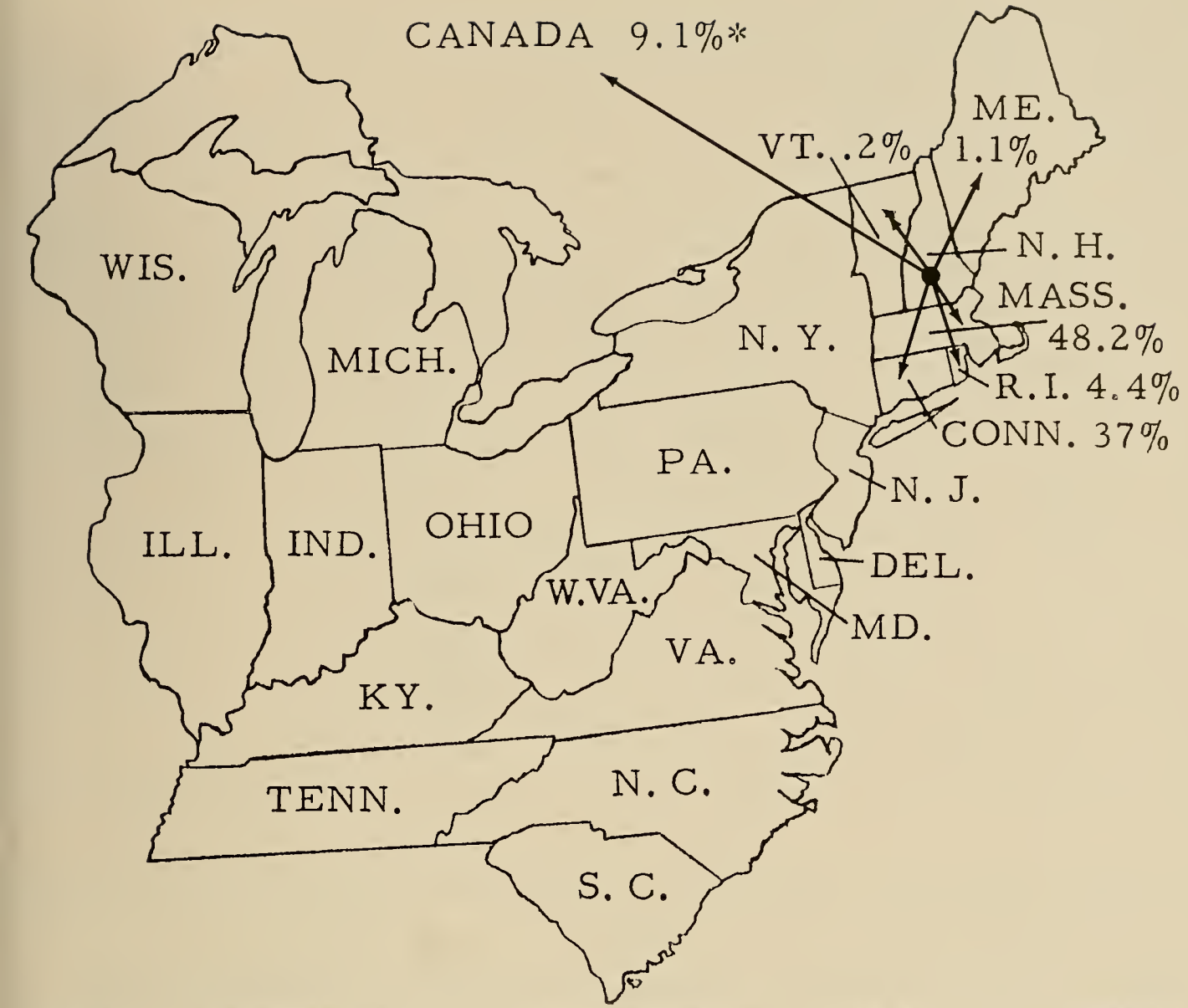

Figure 22. State destination of New Hampshire lumber sold to out-of-state outlets.

*Percentages are proportions of total lumber exported from New Hampshire.

lumber that is produced moves almost entirely into local markets within these states. As a result, the proportions of hardwood grade-lumber being exported to various destinations are almost identical to the proportions of all-lumber exports to the same destination.

\section{LUMBER MARKET CHANNELS}

The type of marketing channel into which lumber moves is more a matter of species class than of geography. It is the end use which governs the channel selected-for softwoods the channel is principally the construction industry, and for hardwoods, it is the manufacture of producers' and consumers' goods. This relationship underlies the fact that the manufacturing outlet was the major outlet, both for in-state and for out-of-state destinations, of hardwood lumber sold by most of the states in the study. The only exceptions to this rule were Maine and New Hampshire. In these two states the largest proportion of hardwood lumber exports moved into wholesale outlets, with manufacturers comprising the second most important channel. 


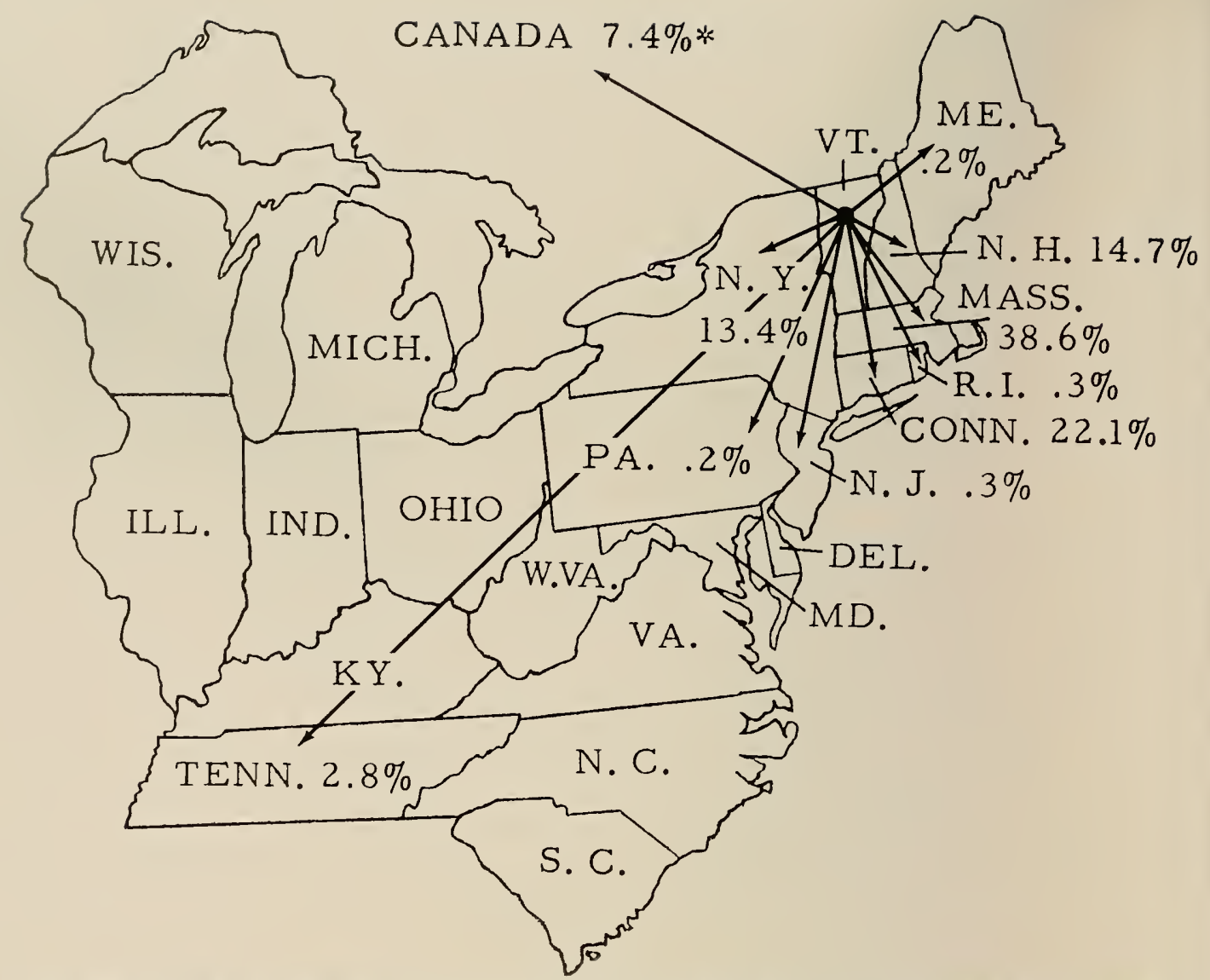

Figure 23. State destination of Vermont lumber sold to out-of-state outlets.

*Percentages are proportions of total lumber volume exported from Vermont.

In-state movement of hardwood lumber in the region was directed predominately toward manufacturers. The lone exception was West Virginia-whose relative lack of secondary wood-processing firms explains the fact that the wholesale channel played the largest role in this state.

Outlets for softwood lumber exhibited more variance between states than did outlets for hardwood lumber. Most of the softwood marketed by Pennsylvania, West Virginia, and Massachusetts moved into the consumer outlet, both for in-state and out-of-state sales. Vermont and Maine marketed their softwood lumber primarily to consumers for instate sales and to wholesalers for out-of-state sales. New Hampshire's softwood lumber was sold principally to wholesalers, irrespective of geographic distribution.

\section{Marketing Practices}

In this bulletin, "marketing practices" refers to such selling activities as terms of sale, product measurement, product grading, and choice of sales outlet. Although price determination and marketing effort would 
also be classified as marketing practices, these activities will be discussed in the following section, entitled "Pricing in the Lumber Market."

\section{TERMS OF SALE}

Terms of sale refers to method of payment and to sales contracts or agreements between buyer and seller.

Of numerous possible methods of payment, the cash sale method (10 to 30 days) predominated, accounting for 90 per cent of the lumber marketed by producers in the states studied. The remaining volume was sold mainly under "deferred settlement"-a method which allows the buyer a period of time following receipt of goods in which to make payment.

The most common type of sales agreement, representing about half of all lumber sold, was a "renewable agreement for a specified quantity of lumber." The remaining volume was fairly evenly marketed among other types of sales agreements, such as a renewable agreement for total production on a yearly basis; fixed agreement for total production for a period of time; and fixed agreement for a given volume in a single sale.

\section{GRADING AND MEASUREMENT}

Lumber can be graded by professional personnel provided by regional lumber manufacturers' associations, or by graders who are employed by the buyer or the seller. In the softwood lumber market, some employee-graders are certified by regional associations.

Employee-graders graded three-fourths of all hardwood lumber sold on standard grades and 95 per cent of all the softwood lumber marketed on standard grades, as reflected in Figure 26. Certified employee-graders graded about one-third of all softwood lumber marketed. The association and certified graders were most commonly used in the larger mills.

Measurement of lumber was found to be correlated with size of operation. Sellers measured 85 per cent of total sales volume of the large mills, whereas about one-half of the volume marketed by small mills was measured by sellers.

\section{CHOICE OF SALES OUTLETS}

As might be expected, the reasons underlying lumber producers' choices of buyers were related to size of operation. Hence, monetary considerations, particularly that of the buyer paying cash on delivery, or a short time thereafter, was the most frequently mentioned reason for choice of buyer by the smaller producers.

By contrast, such factors as long-standing business connections and buyer's reputation were most important to large lumber producers in 


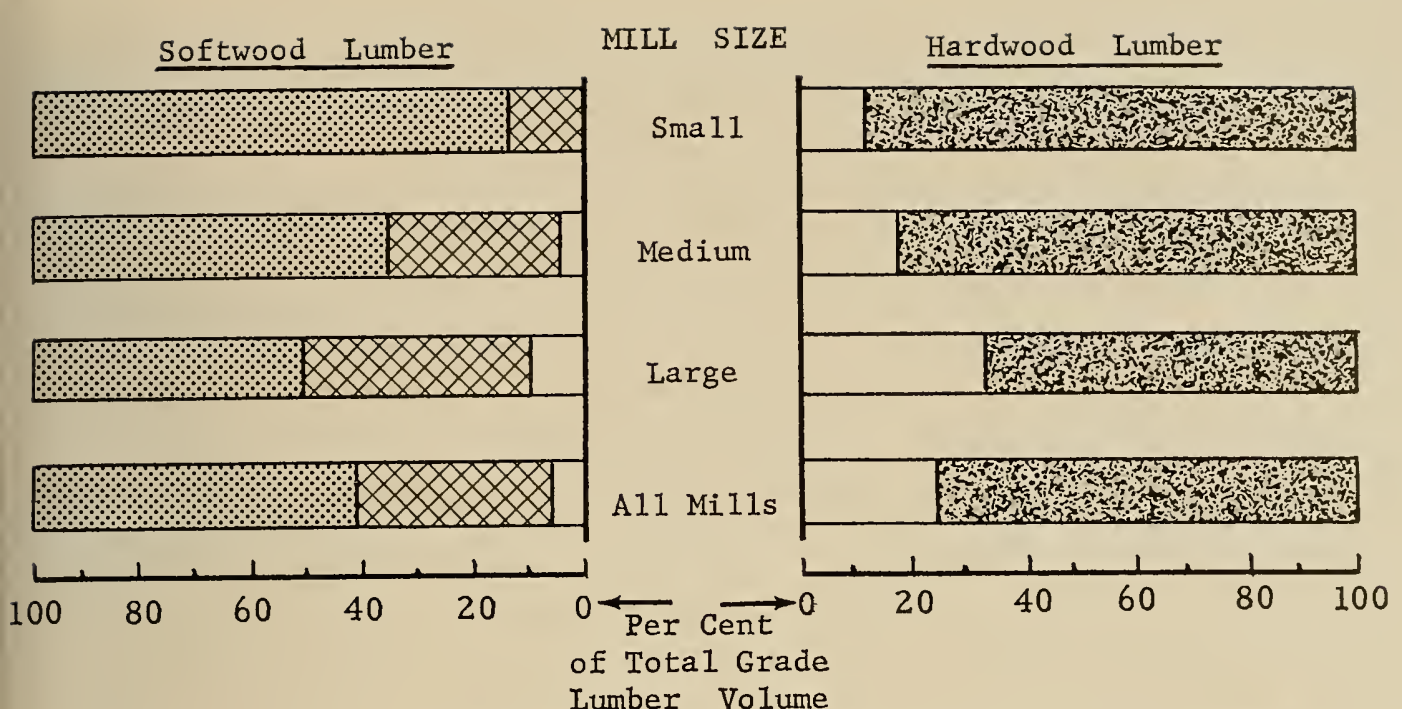
Lumber Volume

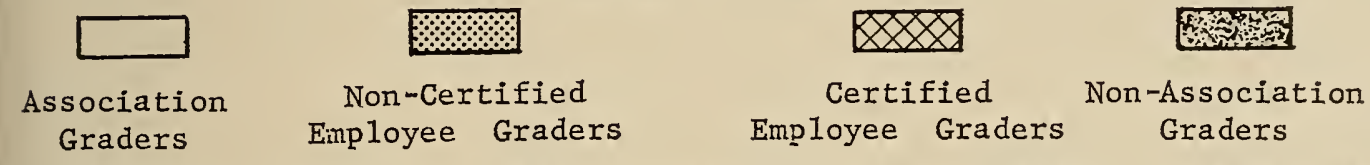

Figure 26. Proportion of graded lumber, by type of grader, mill-size class, and species group.

the states studied. Although monetary considerations appeared to be second in importance to the larger producers, the considerations in these cases were almost totally related to buyers' prices, rather than to time of payment.

Differences were also noted between larger and smaller producers in relation to apparent knowledge of market outlets. For example, one of every three small producers reported that his choice of buyer was based either on the fact that the buyer was one who would come to the mill, or was the only buyer known to him. On the other hand, only 7 per cent of the larger producers listed these particular reasons for choice of buyer.

Other reasons, such as "buyer purchases on grade," "buyer takes all grades," or "can usually sell to buyer when market is poor," were mentioned with about the same degree of frequency by both large and small producers -52 per cent in the case of the smaller producers and 56 per cent for the larger producers. ${ }^{5}$

\section{Pricing in the Lumber Market}

The objective underlying the collecting of price data for this study was to obtain sufficient information to permit a comparison of price averages for other variables-mill-size classes, lumber grades within species groups, and marketing efforts of firms.

${ }^{5}$ Percentages of reasons given, within each producer size-class, are not additive since more than one reason was usually given by a producer. 
No attempts was made to carry out an exhaustive analysis of the pricing mechanisms, since this would involve an entire study in itself, and is thus beyond the scope of the current project.

During interviews, mill owners were asked to give the average F.O.B. mill yard price received per thousand board feet for rough, airdried lumber. These price data were obtained for species (or species groups) and lumber grades.

\section{MILL-SIZE CLASS AND LUMBER PRICES}

Whether for a given species and grade, or for a given species group and class of grades, a distinct relationship existed between weighted average price and marketing-size class of mills. For \#1 Common and Better hardwood lumber, average price ranged from $\$ 127$ per MBF in
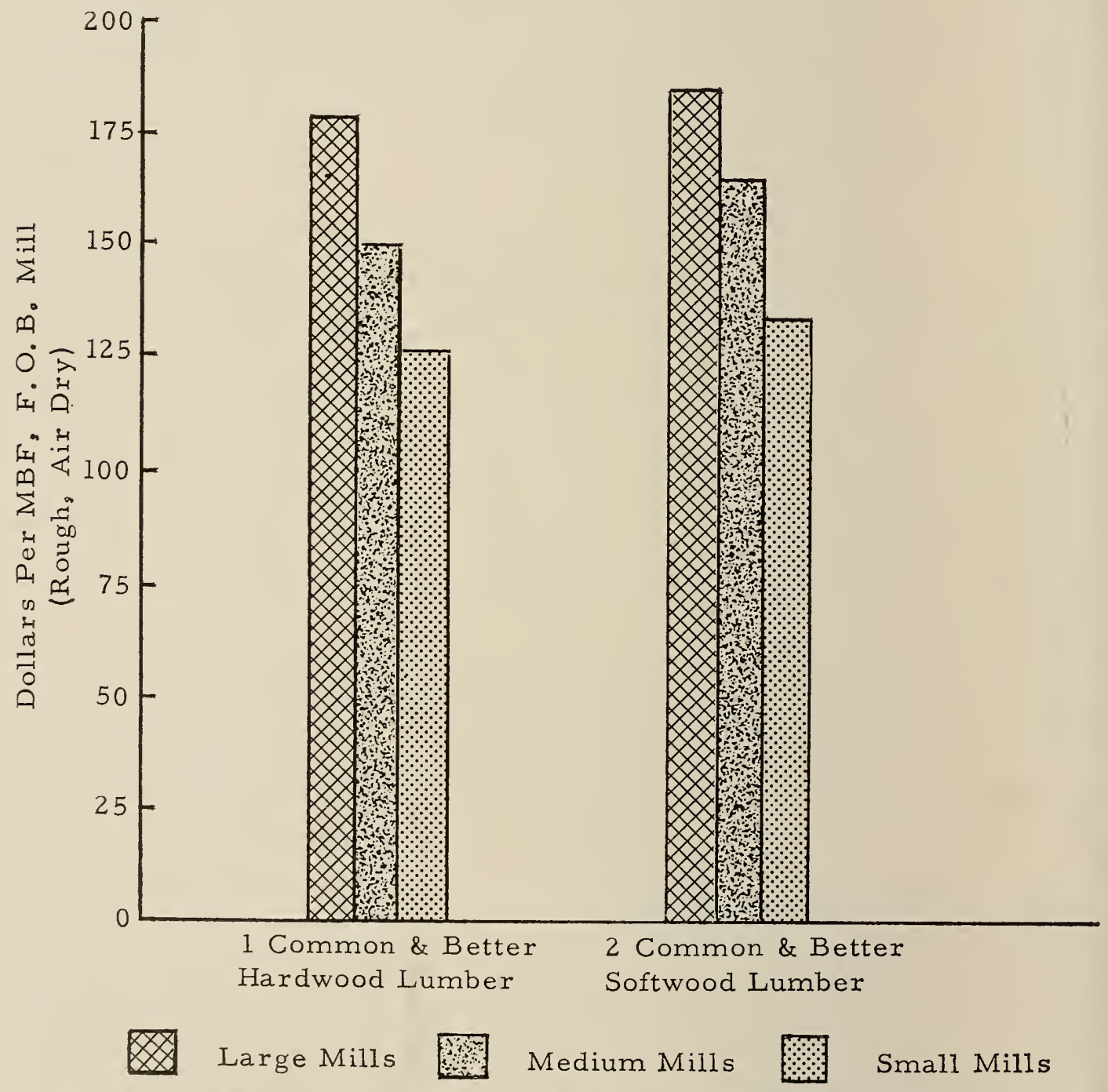

Figure 27. Average price for quality-grade hardwood and softwood lumber in the Northeastern region, by mill-size class. 
small mills to $\$ 177$ per MBF in large mills. Similarly, for $\# 2$ Common and Better softwood lumber, average price ranged from $\$ 134$ per MBF in the small mills to $\$ 183$ per MBF in large mills (Figure 27).

No such progression existed for ungraded lumber. All mill sizes received an average price of about $\$ 70$ per $\mathrm{MBF}$ for ungraded hardwood lumber, and about $\$ 77$ per MBF for ungraded softwood lumber.

The relationship of average price to mill-size class was found to occur for individual species and grade categories in those situations where the process of substratifying sample data did not result in so few reported prices as to prohibit trend formation. Table 2 indicates the effect of mill-size class on weighted average price per $\mathrm{MBF}$ for given species and grades in Maine, Vermont, and West Virginia.

Table 2. Effect of Mill-Size Class on Weighted Average Price Per mBF for Given Species and Grades in Maine, Vermont, and

WEST VIRgINIA

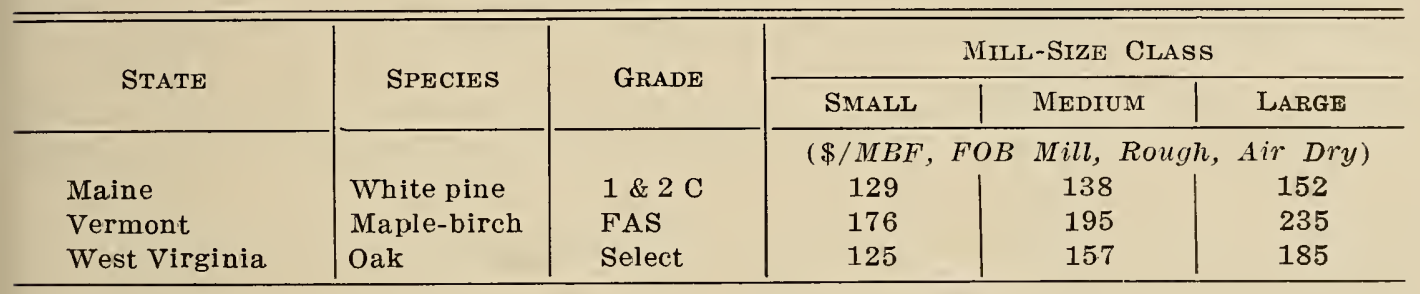

The differences in average price received by the three mill-size classes apparently stems from differences in relative bargaining strength. In small mills, for example, buyers set the price per MBF for almost onehalf of all volume marketed. By contrast, as shown in Figure 28, buyers set the price for only 6 per cent of the total volume sold by the large mills.

As strength of the buyer's bargaining position increases, a logical consequence is reduction in average price received by the seller. It seems reasonable to assume that this may explain, in part, the price differentials between the three mill-size classes.

The decrease of bargaining strength of the seller accompanying decreases in size-class of mill evolves from several factors. First, the smaller the mill, the smaller is the offering in total volume for any given saleto say nothing of offerings for a given species and grade. Hence the buyer has little to lose if the seller will not accept the offered price.

Second, decreased scale of operation is usually accompanied by weaker financial position. Small producers are accordingly less able to tie up capital in yard inventories than are larger producers, as reflected in Figure 29. As a result, there is greater pressure on the smaller producer to accept the offer of the buyer. 


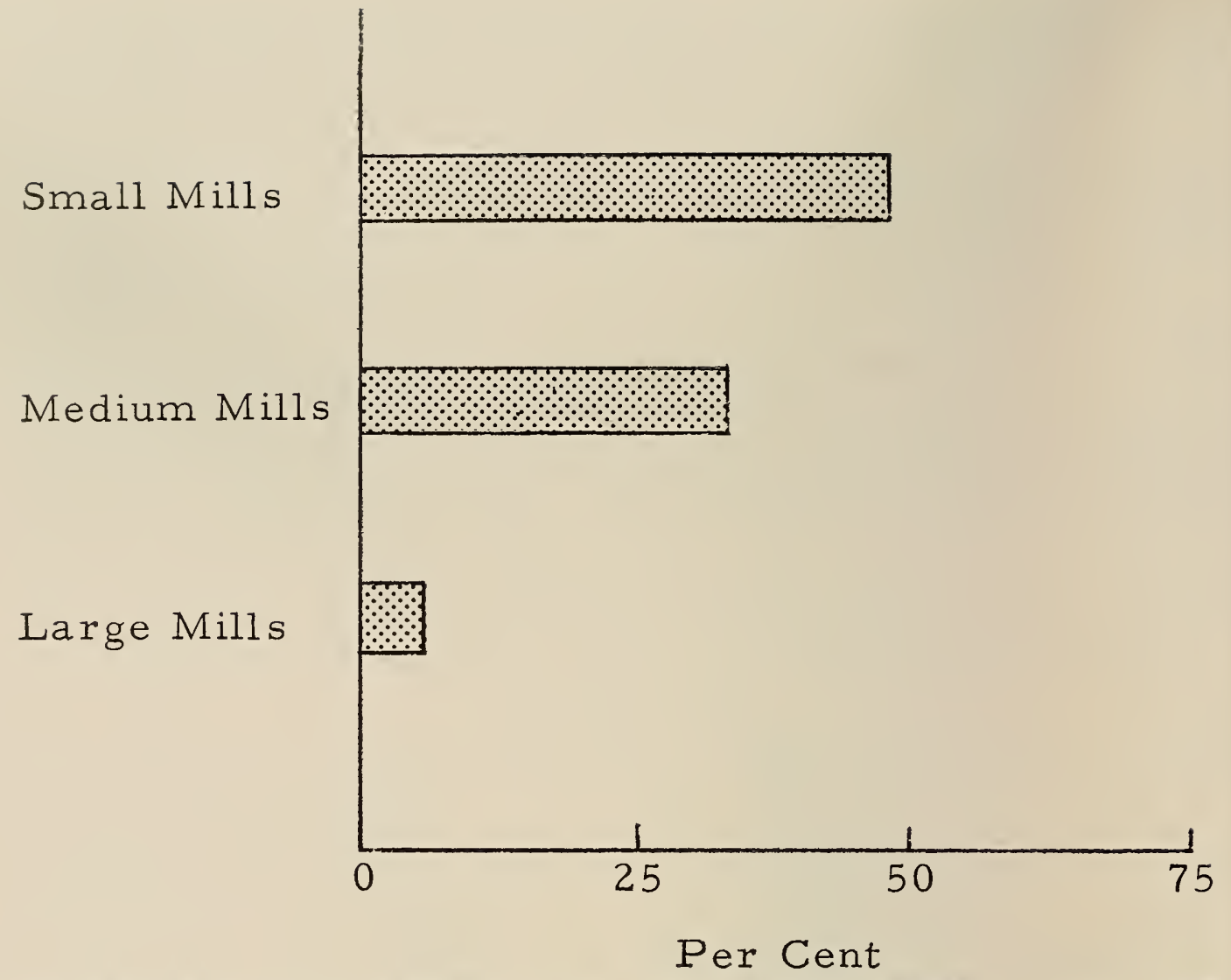

Figure 28. Proportion of total volume within each mill size on which price was established by the lumber buyer.

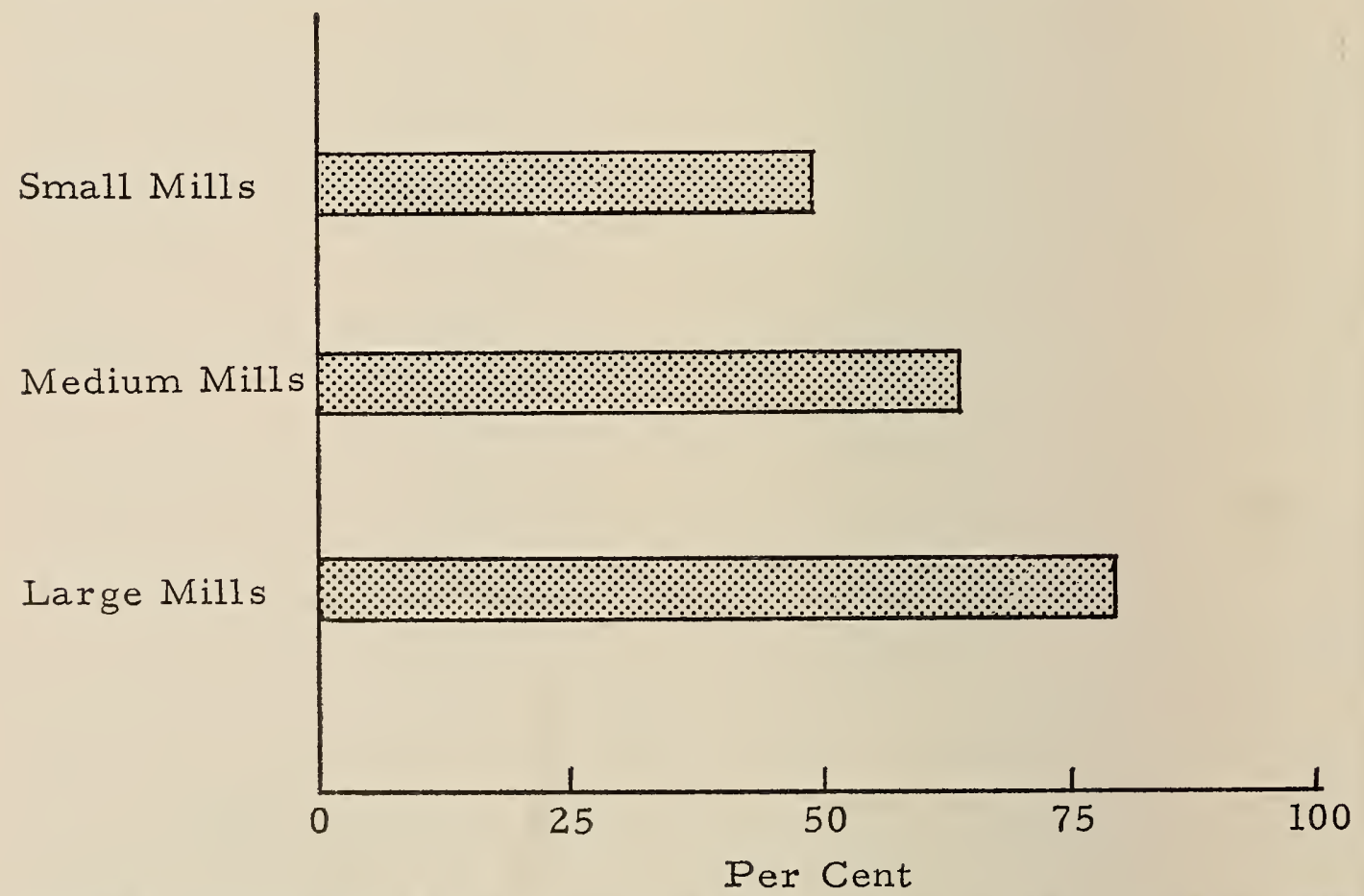

Figure 29. Proportion of total lumber sales volume within each mill-size class sold from yard stocks. 
Third, the inability to hold capital means that the seller is frequently unable to ride out short-term fluctuations of the market. If price is depressed, the smaller producer is not in a position to hold his offerings from the market and build up his stocks in anticipation of a rise in price to its former level.

Other market factors also underlie the average-price differentials for the three mill sizes. Some of these-knowledge of markets, competitive position in the interstate lumber market, and ability to promptly fill orders for large quantities of high quality lumber-were discussed in the section entitled "Market Geography." Interrelated with these is the degree of marketing effort expanded by lumber producers. As Figure 30 indicates, the number of hours spent per month finding markets rises very rapidly with increasing size of mill. With all other factors held constant, it would be logical to expect higher average prices to accompany

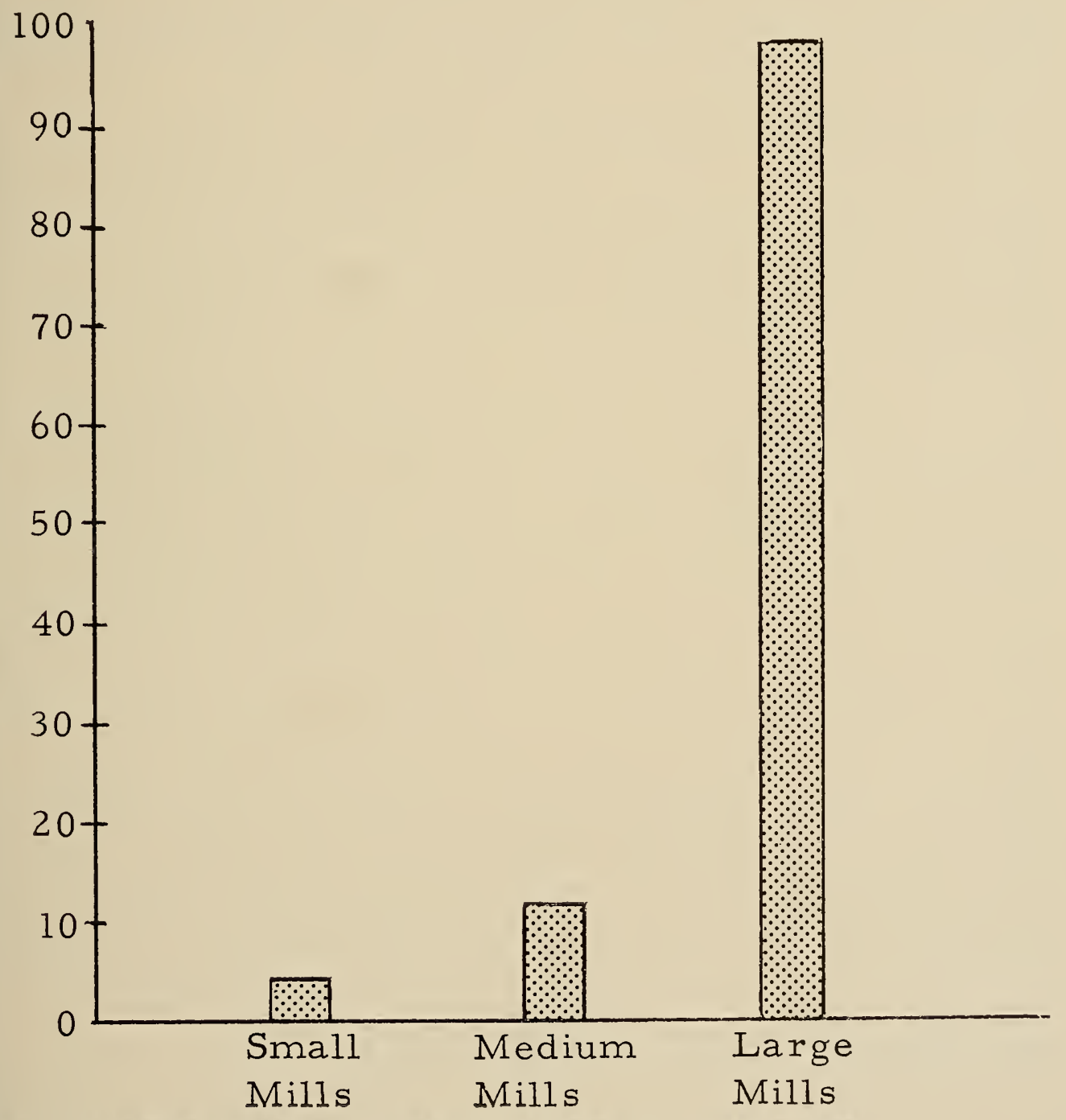

Figure 30. Average time spent locating markets, by mill-size class. 
greater efforts toward development and diversification of market outlets for lumber.

\section{LUMBER GRADE AND PRICING}

The relationship of price to specific grades of lumber needs no amplification, since this relationship is reflected in the price lists and bulletins published periodically by lumber-purchasing firms and trade associations. What is of importance is the comparison of price averages for high quality (\#1 Common and Better in hardwoods; \#2 Common and Better in softwoods) and ungraded lumber.

Average price for quality grade lumber, both hardwood and softwood, was more than twice that of ungraded lumber in the states studied, Figure 31. This differential underscores the importance of producing and marketing for maximum grade yield of lumber. It means that, in terms of regional price averages, every $M B F$ of quality grade lumber lost through poor sawing reduces potential returns by one-half. Similarly, potential returns would be halved for every MBF of quality grade lumber sold on a mill-run or ungraded basis.

The foregoing comparisons are based on averages for all mills, irrespective of size. As was indicated in Figure 27, average price per MBF of quality grade lumber sold by small mills was less than that of the larger mill sizes. However, even in small mills the loss of potential returns accompanying inefficient operation and marketing is close to that reported for all-mill averages.

Thus, returns for every thousand board feet of quality grade hardwood and softwood lumber, sold as mill run or ungraded by small mills, represent but 55 and 57 per cent, respectively, of potential gross returns.

It was not possible, within the scope of this study, to ascertain what proportion of total annual volume marketed on an ungraded basis was, in fact, quality grade lumber. Nonetheless, some indication of the impact, dollar-wise, of inefficiency can be obtained by way of example. For all sample mills interviewed in the survey, sales of ungraded lumber totaled 39,829 MBF for hardwoods and 155,221 MBF for softwoods. If only a tenth of these volumes had been quality grade lumber, and marketed as such, the increase in gross sales for the year studied would have amounted to $\$ 1,567,546$. This increase, based on the assumption that quality grade material would be sold at price averages reflected in Figure 31, provides some indication of the potential which might be realized through more efficient production and marketing practices.

\section{THE PROBLEM OF LOW GRADE LUMBER}

An almost universal complaint of lumber producers was the difficulty experienced in attempting to market, at a profit, lumber of the 
Hardwood

Lumber

Softwood

Lumber

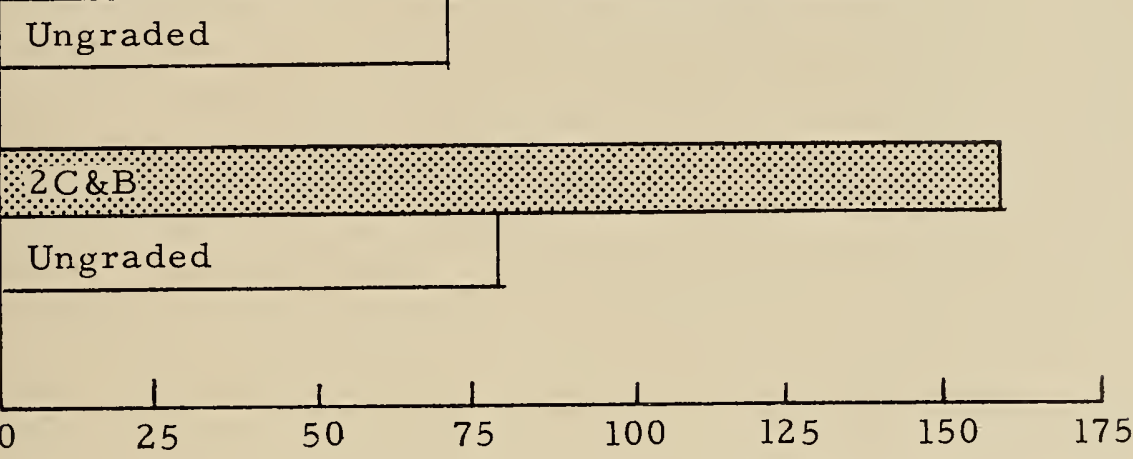

Dollar.s Per MBF, F. O.B. Mill

(Rough, Air Dry)

Figure 31. Average price received for graded and ungraded lumber in the region.

poorer standard grades-\#2 Common and Poorer for hardwoods and \#3 Common and Poorer for softwoods.

The existence of the problem is indicated by the price averages for these grades. For softwood lumber, the average price of \#3 Common and Poorer lumber was identical to that of ungraded lumber. For hardwood lumber, the average price for ungraded lumber exceeded that for $\# 2$ Common and Poorer by $\$ 14$ per MBF.

It follows then that no particular advantage is gained in producing and marketing lumber in these poorer standard grades, especially in hardwood lumber, where ungraded lumber has a higher average price. As a consequence, some mills adopt a policy of producing and selling their extra output on a mill-run basis.

This practice, in turn, means that some quality grade lumber also is sold on an ungraded basis-with the results described earlier.

The problem, then, is twofold. Lack of markets for lumber in poorer grades depresses average prices and prevents producers from handling lumber in these grades at a profit, and the low price structure results in a tendency of a certain proportion of lumber producers to market all output on a mill-run basis, thus creating inefficiency in marketing quality grade lumber.

Until new markets develop for lumber in the poorer standard grades, it is likely that the problem as outlined above will continue to exist. Answers to the problem would seem to lie in research on profitable utilization of low grade materials, including investigations in the area of new wood product development. 


\section{Conclusion}

The forest product marketing research that has been performed in the Northeastern region has pointed out the similarity of problems that exist among small-woodland owners and small-sawmill operators. Both lack the resource to control or perform many of the marketing functions. They are forced to rely on the buyer of their products to carry out such marketing activities as grading, measuring, and pricing. Furthermore, the small-sawmill operator is frequently forced to sell, regardless of the market advantage, because of inadequate storage facilities or financing.

The question then arises-to what extent should small-woodland owners and small-sawmill operators be encouraged to remain in business. Regardless of the degree of encouragement, they will continue to exist and to affect the marketing of forest products. Therefore, it is important that these producers be adequately informed through collective action, such as by operators' associations, market reports, and directories.

The sawmill operator must produce and market his product efficiently so as to compete favorably with other sawmills, and so that his product may compete with other materials such as steel, plastic, and aluminum. It therefore is particularly important that the operator know the needs of the customer and that he produce a product that meets these needs. This calls for technical skill in mill operation and some form of quality control. Furthermore, if the operation is to remain on a sound basis, the need exists for accurate cost accounting. This will allow a basis for management decisions relative to expansion of mill equipment and services.

Although the development of new products is primarily outside the role of the sawmill operator, research should be performed in this area in order that wood as a raw material may be utilized to contribute to the economic growth of the region at the highest possible level. 



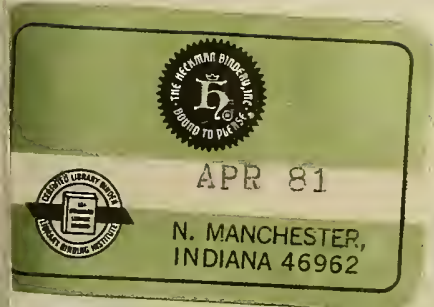


